\title{
Zimbabwe: 2004 Article IV Consultation-Staff Report; Staff Statement; and Public Information Notice on the Executive Board Discussion
}

Under Article IV of the IMF's Articles of Agreement, the IMF holds bilateral discussions with members, usually every year. In the context of the 2004 Article IV consultation with Zimbabwe, the following documents have been released and are included in this package:

- the staff report for the 2004 Article IV consultation, prepared by a staff team of the IMF, following discussions that ended on March 31, 2004, with the officials of Zimbabwe on economic developments and policies. Based on information available at the time of these discussions, the staff report was completed on June 10, 2004. The views expressed in the staff report are those of the staff team and do not necessarily reflect the views of the Executive Board of the IMF.

- a staff statement of July 7, 2004, updating information on recent economic developments.

- $\quad$ a Public Information Notice (PIN) summarizing the views of the Executive Board as expressed during its July 7, 2004 discussion of the staff report that concluded the Article IV consultation.

The document listed below have been or will be separately released.

\section{Statistical Appendix}

The policy of publication of staff reports and other documents allows for the deletion of market-sensitive information.

To assist the IMF in evaluating the publication policy, reader comments are invited and may be sent by e-mail to publicationpolicy@imf.org.

$$
\begin{gathered}
\text { Copies of this report are available to the public from } \\
\text { International Monetary Fund • Publication Services } \\
70019^{\text {th }} \text { Street, N.W. • Washington, D.C. } 20431 \\
\text { Telephone: (202) 623-7430 • Telefax: (202) 623-7201 } \\
\text { E-mail: publications@imf.org • Internet: http://www.imf.org }
\end{gathered}
$$

Price: $\$ 15.00$ a copy

\section{International Monetary Fund \\ Washington, D.C.}



INTERNATIONAL MONETARY FUND

ZIMBABWE

\title{
Staff Report for the 2004 Article IV Consultation
}

\author{
Prepared by the Staff Representatives for the 2004 Consultation with Zimbabwe \\ Approved by Michael Nowak and Juha Kähkönen
}

June 10, 2004
- $\quad$ Discussions were held in Harare during March 16-31, 2004. The staff met with the Ministers of Finance and Economic Development; Land, Land Reform and Resettlement; Anti-Corruption and Anti-Monopoly Policy; Industry and International Trade; Health; the Governor of the Reserve Bank of Zimbabwe, and other senior government officials. It also met with representatives of NGOs, the business and financial sector, political parties, trade unions, and the diplomatic community.
- $\quad$ The team consisted of D.C. Ross (head), F. Ahmed, J-F. Dauphin, A. Jayaratnam (all AFR), H. Treichel (FIN), D. Rozhkov (MFD), and P. Khandelwal (PDR). J. Mafararikwa, Advisor to the Executive Director for Zimbabwe, and World Bank staff participated in some of the discussions.
- Zimbabwe is on the standard 12-month consultation cycle. At the conclusion of the 2003 Article IV consultation on June 6, 2003, Executive Directors expressed deep concern about the continued sharp decline in economic activity and per capita income, the rise in poverty and human suffering, the repeated shortages of food, the acceleration of inflation, and the accumulation of external payments arrears. They noted that the deteriorating situation was the result of inappropriate economic policies, aggravated by violence and disruptions to productive activity related to the government's fast-track land reform program. They urged the authorities to implement policy changes to prevent a worsening of the situation.

- Zimbabwe has accumulated overdue financial obligations to the Fund since February 2001; these arrears totaled SDR198 million as of end-May 2004. Following a decision by the Executive Board on December 3, 2003, the Managing Director issued a complaint on February 6, 2004 that initiated the procedure on Zimbabwe's compulsory withdrawal from the Fund.

- $\quad$ Zimbabwe accepted the obligations of Article VIII, Sections 2, 3, and 4, but maintains exchange restrictions and multiple currency practices subject to Fund approval. In the absence of a timetable to remove the restrictions, the staff does not recommend their approval by the Fund. In addition, it has incurred external payments arrears on official debt.

- Z Zimbabwe's economic data suffer increasingly from poor coverage, time lags, and worsening reliability of reporting units, all of which hamper Fund surveillance. 
Executive Summary

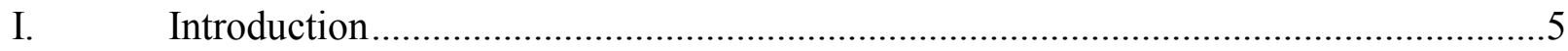

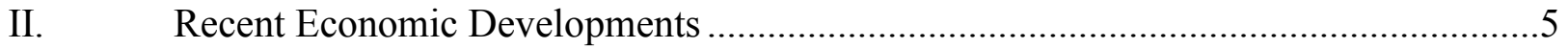

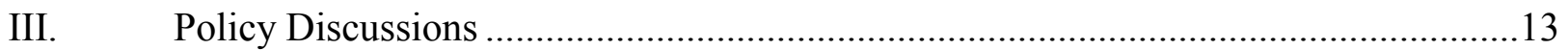

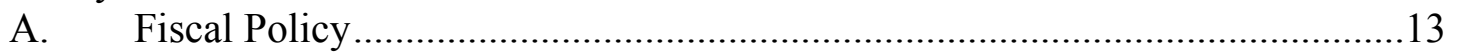

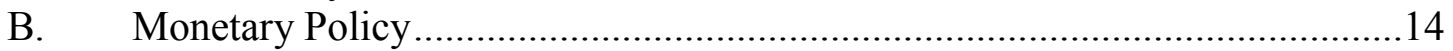

C. Exchange Regime, Price Controls, and Regulation ....................................16

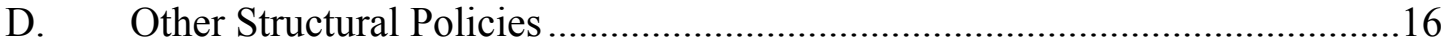

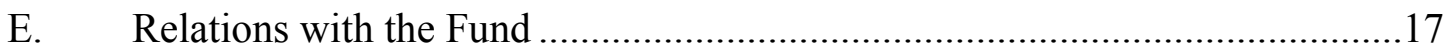

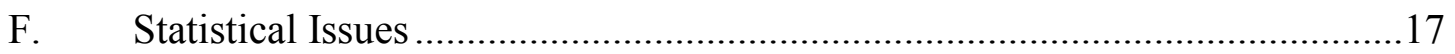

G. Medium Term Outlook ....................................................................... 18

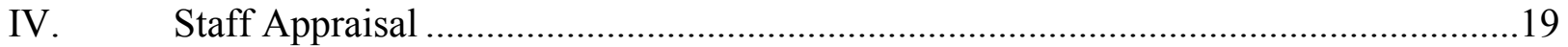

\section{Boxes}

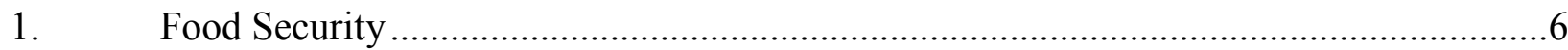

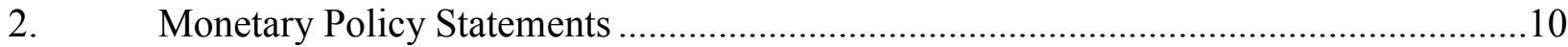

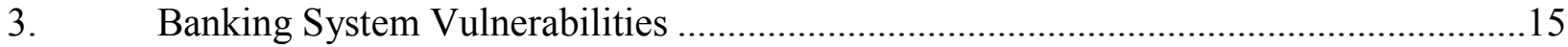

Figures

1. Budget Balance, Including Grants (Cash Basis) ......................................................

2. Money Growth, Inflation and Parallel Exchange Rate ............................................9

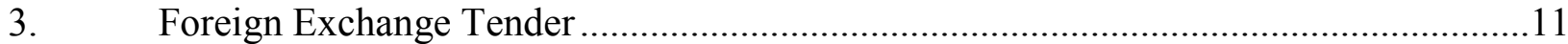

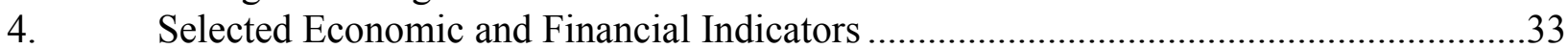

Tables

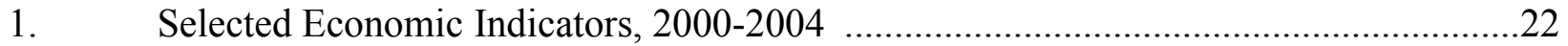

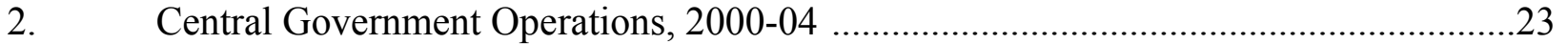

3. Monetary Survey, 2000-2004 .............................................................................25

4. Financial Soundness Indicators for the Banking Sector, December 2003 ...................27

5. Summary Results of Stress Tests, end-December 2003 .........................................28

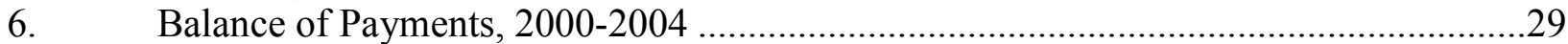

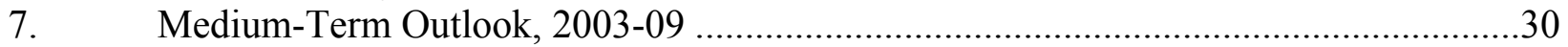

8. External Debt Sustainability Framework, Baseline Scenario, 2000-2023 ..................31

9. Sensitivity Analyses for Key Indicators of Public and Publicly Guaranteed External

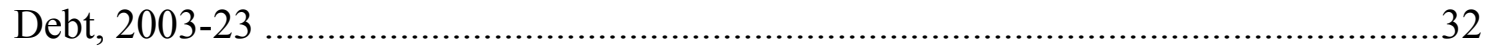

Appendices

I. Social Issues 


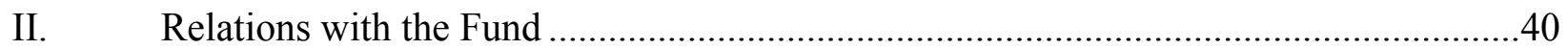

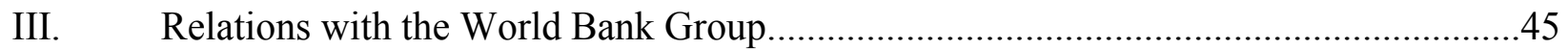

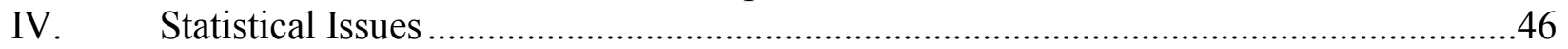

V. Illustration of Zimbabwe's External Debt Situation.............................................50 


\section{EXECUTIVE SUMMARY}

- Zimbabwe's overall economic and social situation has continued to deteriorate. Real GDP fell by some 30 percent over the last 5 years, and another decline of 4 5 percent is projected this year. Structural changes have weakened the economic base; in particular, the disorderly implementation of the land reform program has sharply reduced agricultural production and contributed to widespread food shortages. Concerns about economic and political governance have discouraged productive investment and promoted capital flight and emigration. Inflation reached 600 percent in November 2003, but has eased in recent months. Real wages and formal sector employment have fallen sharply, and social conditions are dire. The food security situation remains difficult, but sizable donor assistance has helped meet food and other humanitarian needs over the last two years. Poverty levels continue to rise and the HIV/AIDS pandemic remains largely unchecked.

- Economic policies lack consistency and have not adequately dealt with these challenges. Loose monetary policy in 2003 provided credit to the private sector at very low nominal interest rates and accommodated inflationary pressures. The Reserve Bank (RBZ) has made inflation reduction its prime target since December 2003 and has tightened monetary policy, but not consistently and without support from fiscal policy. The managed foreign exchange tender introduced in January 2004 led to an appreciation of the average exchange rate as the parallel market was sharply curtailed and driven underground. Reflecting the impact of higher-than-budgeted inflation, fiscal operations were almost balanced in 2003, but the 2004 budget is expansionary. Progress was made in 2003 in reducing price controls, but corruption is widespread and the monopoly of the Grain Marketing Board (GMB) remains in place.

- The policy discussions focused on arresting the economic decline and restarting growth. The mission welcomed some of the steps taken since late 2003, including strengthened supervision of financial institutions, but urged more action on fiscal, monetary and exchange rate policies. It advised to monitor closely the impact of tighter monetary conditions on the banking sector and to preserve social spending from the fiscal tightening. It also recommended the implementation of necessary structural reforms to increase productivity throughout the economy, particularly in agriculture, where problems relating to the land reform program and property rights have continued to hamper production. The authorities broadly agreed with the thrust of the mission's assessment, but differed on the timing and some of the specifics of the recommendations on financial policies and especially on structural issues. They felt that in the short run export incentives should be provided through ad-hoc support schemes rather than full exchange rate adjustment, and that the dual interest rate policy was still needed to support production. They indicated no immediate intention to revise the 2004 budget, nor to dismantle the GMB monopoly, and have yet to fundamentally address the problems that resulted from the implementation of the land reform. 


\section{INTRODUCTION}

1. Zimbabwe's economy has continued to deteriorate. Real GDP declined by 30 percent in the last 5 years and a further decline of 4-5 percent is expected this year. Inflation doubled in each of the last 3 years and reached 600 percent at end-2003. While this is in part the result of shocks, such as inclement weather, it mainly reflects the inadequacy of economic policies. Moreover, structural changes weakened the economic base. In particular, the disorderly implementation of the land reform program has sharply reduced agricultural production. Concerns about governance, the rule of law and human rights, and continued lack of clarity about property rights have severely damaged confidence, discouraged investment, and promoted capital flight and emigration.

2. The economic decline has had dire social consequences. Unemployment is very high and increasing, social indicators have worsened, and the HIV/AIDS pandemic remains largely unchecked, with one in four adults being HIV-positive (Appendix I). Severe food shortages have necessitated massive food imports and donor assistance (Box 1) — and a vicious cycle of malnourishment and disease has developed. Prices have risen much faster than incomes, especially among low-income earners. Financial savings have been eroded by inflation and low nominal interest rates. Public services have deteriorated and are unable to cope with demands.

3. The political situation has become increasingly difficult. Attempts by diplomatic channels to broker talks between the ruling party Zanu-PF and the opposition party Movement for Democratic Change (MDC) have not yielded results. Zanu-PF recently won local elections amidst reports of fraud and political violence. In several cities with elected MDC mayors, centrally appointed governors were imposed. The treason trial of MDC leader Tsvangirai continues, and the only daily independent newspaper was shut down in September 2003. Amendments to the electoral act in March 2004 granted greater powers to the registrar general and provided compulsory "voter education", and the authorities rejected a UNDP proposal to help finance and monitor the March 2005 general elections.

4. International relations have further deteriorated. The international community has expressed grave concern over a lack of respect for basic democratic principles, human rights, good governance and the rule of law. The US and the European Union have renewed and extended their targeted sanctions against President Mugabe's regime. In December 2003, Zimbabwe withdrew from the Commonwealth when it was indefinitely suspended. Donor support is limited to humanitarian assistance.

\section{RECENT ECONOMIC DEVELOPMENTS}

5. Real GDP declined by 9.3 percent in 2003 with agriculture, mining, manufacturing, and tourism being the most affected sectors (Table 1). On the supply side, shortages of domestic and imported inputs, and rising production costs contributed to the drop in production. Furthermore, the decline in productivity and shortages of labor brought about by the HIV/AIDS pandemic, combined with the poor maintenance of infrastructure, have 


\section{Box 1. Food Security}

Zimbabwe's population continues to face food shortages. While cereal production, especially maize, rose by $1 / 3$ in the crop year ending in 2003, it was still less than half of average production during 1997/98-2001/02. Contributing factors to the low production levels include unfavorable weather conditions, the disruption of large-scale farming by the government's fast track land reform, and input shortages.

Over 6 million people ( $1 / 2$ of the total population) were in need of food assistance in early 2004 . The majority live in rural areas, mainly unemployed former commercial farm workers. The World Food Program (WFP) and its partners have not been able to provide food aid to all in need because the donor response to its appeal for food assistance has been insufficient. Urban food security has become a growing problem; the WFP does not target urban households and there are few government support programs in these areas.

Most observers expect the cereal gap to persist beyond March 2004 owing to poor prospects for any increase in production above last year's level. In contrast, the Ministry of Agriculture estimates the current cereal crop at 2.8 million tons in - more than double last year's result-and in May 2004 cancelled the joint crop assessment undertaken in previous years with WFP/FAO. At the same time, the government is reportedly making preparations for large-scale grain imports (600,000-700,000 tons) from mid-2004.

Cereal Balance Sheet, 2002/03-2003/04 (April-March)

(in thousands of metric tons)

\begin{tabular}{|c|c|c|c|}
\hline & $\begin{array}{l}\text { Five-Year } \\
\text { Average }^{1}\end{array}$ & $\begin{array}{r}2002 / 03 \\
\text { Prel. }\end{array}$ & $\begin{array}{r}2003 / 04 \\
\text { Est. }^{2}\end{array}$ \\
\hline Opening Stock & 555 & 183 & 88 \\
\hline Production & 2,164 & 749 & 1,007 \\
\hline Total Availability & 2,719 & 932 & 1,095 \\
\hline Domestic Requirements & 2,888 & 2,583 & 2,382 \\
\hline Domestic Cereal Gap & -169 & $-1,651$ & $-1,287$ \\
\hline Government imports (projected) & 198 & 1,041 & 545 \\
\hline Of which received & $\ldots$ & $\ldots$ & 372 \\
\hline Other imports & 0 & 30 & 50 \\
\hline Food aid (expected) & 1 & 328 & 391 \\
\hline Of which received & $\ldots$ & .. & 310 \\
\hline Unfilled cereal gap $(-) /$ surplus $(+)$ & 30 & -252 & -301 \\
\hline Memorandum item: & & & \\
\hline $\begin{array}{l}\text { Population assumption (in } \\
\text { millions) }\end{array}$ & 13.7 & 11.6 & 11.7 \\
\hline
\end{tabular}

Sources: Famine Early Warning System Network (FEWSNET); WFP.

1 1997/98-2001/02.

${ }^{2}$ Preliminary estimate, World Food Program, as of February 29, 2004. 
reduced Zimbabwe's growth potential. On the demand side, real consumption has contracted and investment remains at very low levels, reflecting weak investor confidence, excess capacity in major industries, and the lack of foreign exchange for imports. Recorded exports and imports declined in 2003.

\section{Fiscal operations shifted from a deficit of 3 percent of GDP in 2002 to virtual} balance in 2003, with a good result in the last quarter dominating the outcome for the whole year (Figure 1 and Table 2). Revenue declined by 1.5 percentage point of GDP, as real corporate tax revenue, which is collected with a one-year lag, was further eroded by inflation and customs duties were affected by the drop in recorded imports. However, collections were relatively strong late in the year, mainly due to bracket creep on personal income taxes. Expenditure remained within the supplementary budget ceiling notwithstanding higher-than-budgeted inflation, thus registering a significant fall relative to GDP. ${ }^{1}$ Domestic interest payments dropped as interest rates were kept artificially low, spending on goods and capital projects was reduced owing to the foreign exchange shortage and weakening administrative capacity, and government wages fell in real terms.

Government domestic debt fell by $2 / 3$ to 10 percent of GDP at end-2003, reflecting highly negative real interest rates on Treasury bills. Quasi-fiscal operations, which had been large in 2002, were limited in 2003 to exchange rate subsidies for government operations amounting to 0.6 percent of GDP. Several public enterprises ran large deficits in 2003, including the Grain Marketing Board (GMB), but little data are available.

Figure 1. Zimbabwe: Budget Balance, Including Grants (Cash Basis), 2002-04

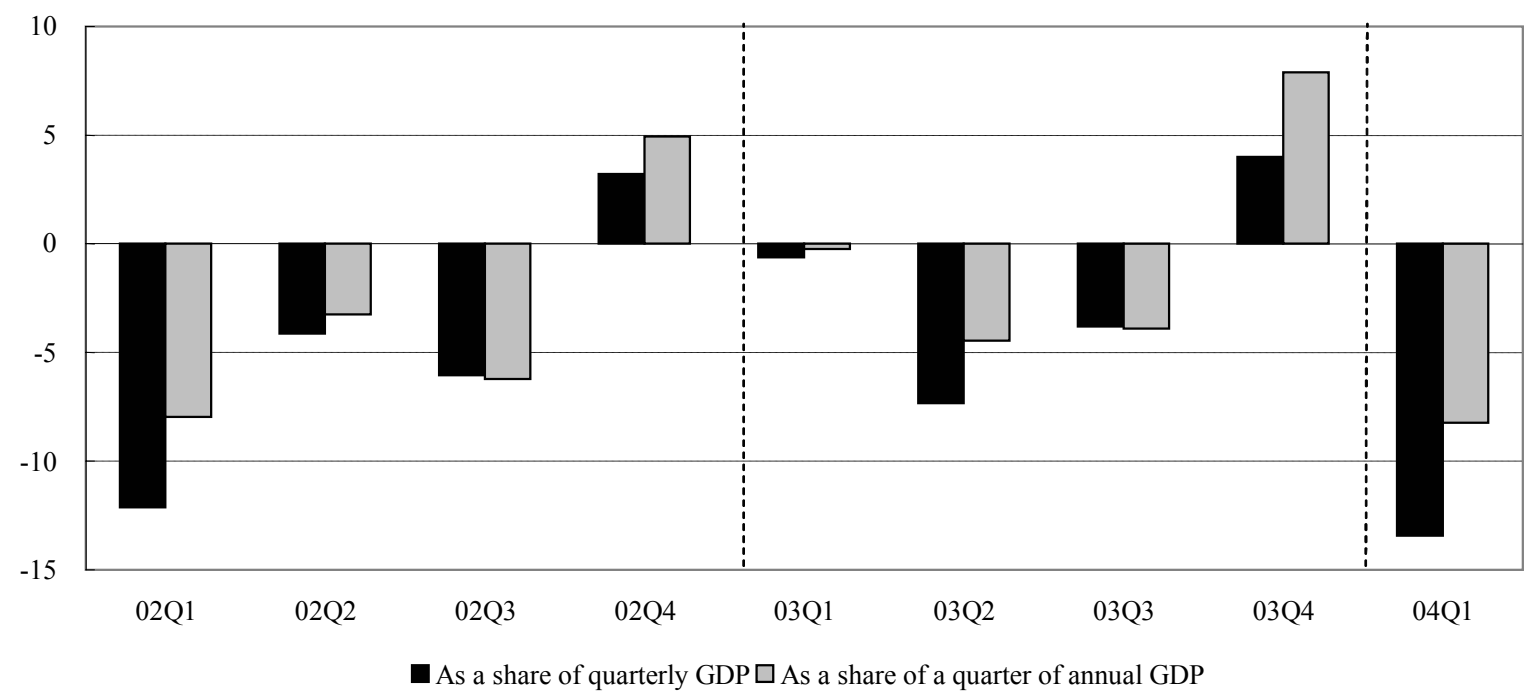

${ }^{1}$ The mission found no evidence of significant domestic payment arrears. 
7. Compared to the 2003 outcome, the 2004 budget appears expansionary, with a deficit target of over 7 percent of GDP. However, the authorities did not plan any major change in revenue, spending or the overall fiscal stance when the 2004 budget was drafted in September 2003, as they still expected to incur a large deficit in 2003. ${ }^{2}$ The 2004 budget contains only few policy measures, including the introduction in January of the VAT (which was remarkably smooth) and of a new levy on petroleum products to assist in reducing the debt of NOCZIM, the national oil company. The February decision to move customs valuation to the tender exchange rate is expected to provide a windfall gain of about 1 percentage point of GDP. The level and composition of expenditure in the 2004 budget shows little change relative to the supplementary budget for 2003, but all spending categories related to GDP are higher than the 2003 outcome. ${ }^{3}$ The budget includes various measures to strengthen expenditure control and auditing, including the extension of the coverage of the computerized financial management system and the setting up of a new ex-post auditing unit in the MFED. In addition, it envisages that all enterprises are to be put on a commercial footing in 2004, without specific indications on how this is to be achieved. Budget execution during the first quarter of 2004 resulted in a deficit of 13.4 percent of quarterly GDP, with the front-loading of the budgeted wage increase (220 percent) in January, and a high level of non-wage outlays. An arbitrator awarded another 50 percent wage increase to the public sector in May, retroactive to January.

\section{Loose monetary policy fueled high inflation and a depreciation of the} Zimbabwean dollar in the parallel market in 2003 (Figure 2 and Table 3). Broad money growth accelerated throughout 2003 spearheaded by an expansion in private sector credit. This was facilitated by the continuation of a dual-interest rate policy under which credit to "productive sectors" was allocated at highly negative real interest rates, while other credit (especially for consumption and real estate purchases) was at market-determined rates. The availability of cheap credit and inflation-hedging behavior led to a sharp rise in stock and real estate prices. At the same time, the exchange rate in the parallel market, which was illegal, but tolerated, depreciated at a fast pace.

\footnotetext{
2 The 2004 budget was based on the assumption that year-on-year inflation would decline to 175 percent by December 2004, with average inflation increasing to 580 percent.

${ }^{3}$ The expenditure side of the budget is difficult to analyze as a large contingency reserve accounts for 15 percent of total expenditure.
} 
Figure 2. Money growth, inflation and parallel exchange rate

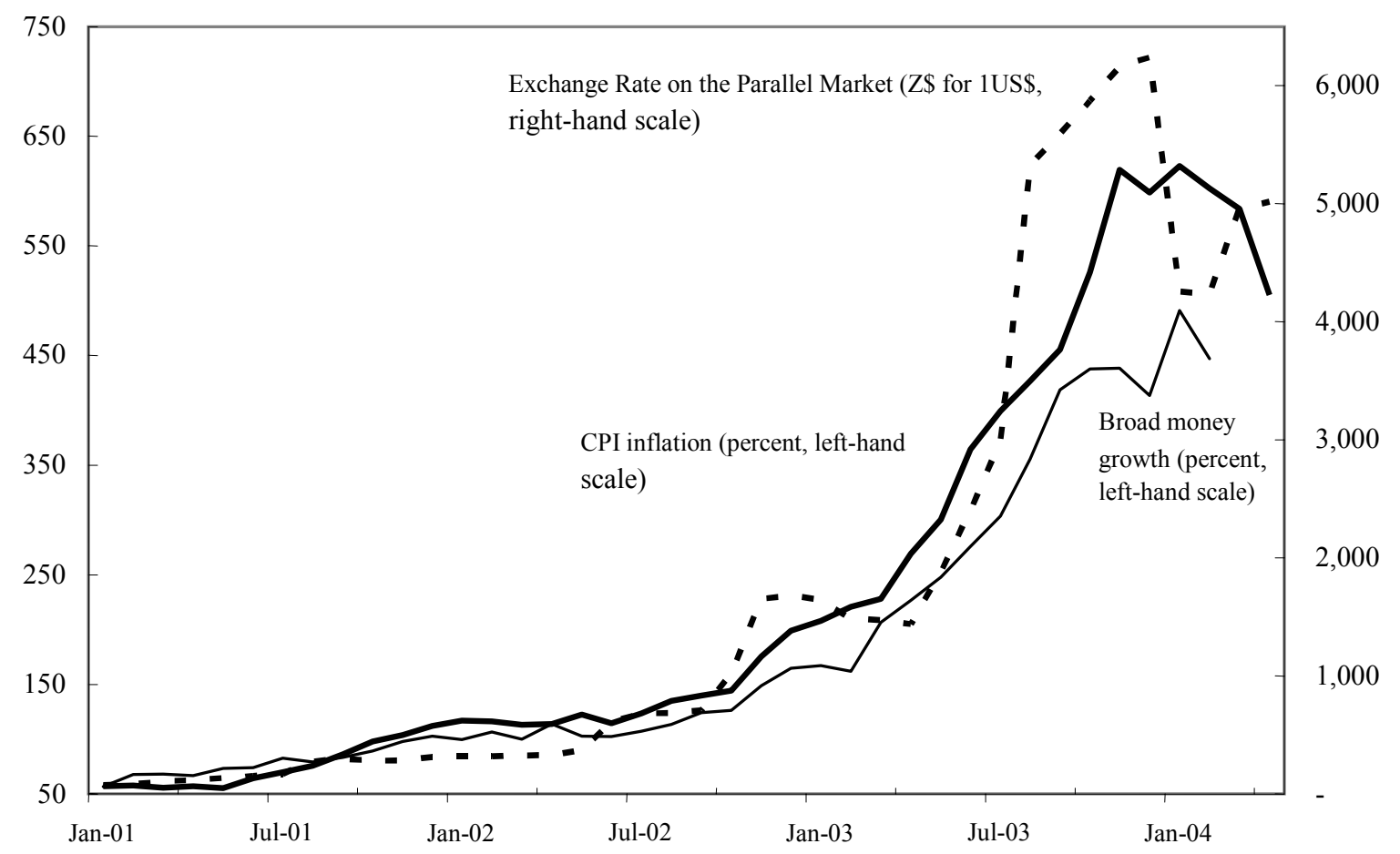

9. Monetary policy was tightened in late 2003, but this policy was not sustained. The new Reserve Bank (RBZ) Governor Gono announced measures in December 2003 to tighten monetary conditions (Box 2) that curtailed access by banks to RBZ liquidity support. The measures drove up interbank rates, causing stock and real estate prices to plummet and putting significant stress on the banking system. In response, in early 2004, the RBZ loosened its stance and started to inject massive liquidity into the financial system through (i) a Productive Sector Finance Facility (PSFF) at a concessional rate of 30 percent, and (ii) a Troubled Bank Fund (TBF) with interest rates ranging from 800 to 1,150 percent in effective terms. The RBZ then began to mop up excess liquidity thus created with new RBZ paper at effective interest rates of over 900 percent, but at the same time continued to provide cheap credit through the PSFF. Despite difficulties encountered by a few mostly small institutions in late 2003-early 2004, the banking system as a whole weathered the economic crisis well (Box 3).

\section{The introduction of new foreign exchange regulations and a clamp down on} parallel market activities led to a currency appreciation in early 2004 (see Box 2). The RBZ introduced in early 2004 a managed foreign exchange tender to carry out all foreign exchange transactions, except for 25 percent of export earnings that have to be surrendered at a more appreciated rate of Z\$824/US\$ for the use of the government. At the same time, the authorities clamped down on the parallel market, notably in the context of a new anticorruption campaign, which led to a sharp reduction of transactions in this market. This 
Box 2. Monetary Policy Statements

The authorities target a reduction in inflation (end of year) from 600 percent in 2003 to 200 percent in 2004 .

December 2003 statement:

- $\quad$ Tightened access to RBZ liquidity support and higher reserve requirements effective January 2004 (reserve requirements were increased from 20 to 30 percent for commercial and merchant banks and from 5 to 15 percent for finance houses).

- Strengthened prudential supervision by assessing the liquidity position of financial institutions and imposing stringent conditions before providing liquidity support and/or access to electronic clearing. Bank licensing authority was transferred from the MFED to the RBZ.

- Expanded dual interest rate policy: a "Productive Sector Finance Facility" (PSFF) provides credit at 30 percent interest to encourage economic growth, while other credit (for consumption, and real estate) is at market-related rates.

- New heavily managed foreign exchange tender (“auction") since mid-January 2004: foreign exchange from surrender requirements, liquidation of FCAs and other sources is auctioned twice weekly by the RBZ. Bids are scanned and bids for non-priority purposes are rejected. Allocations are made at the bidding price starting from the highest accepted bid. Suppliers receive the average rate paid by bidders. Bids are reportedly strongly influenced through moral suasion.

- New surrender requirements for exporters: beginning in early 2004, exporters have to surrender 25 percent of their gross export receipts to the RBZ at the official rate of Z\$824/US\$1 and another 25 percent to the "auction." The remaining 50 percent can be retained in foreign currency accounts (FCAs) for up to 21 days, after which unused foreign exchange has to be surrendered for tender.

- New capital requirements (based on Basel II) for financial institutions as of September 30, 2004: the minimum capital requirement was increased from $Z \$ 500$ million to $Z \$ 10$ billion (about US\$1.6 million at the end-03 parallel market rate).

April 2004 statement:

- New export incentives: (i) a guaranteed floor rate of Z\$5,200/US\$ for exporters at the foreign exchange tender; (ii) enhanced tax credits for 15 percent of exports; and (iii) a new concessional credit facility for 90-day "post shipment foreign currency bills" at LIBOR+5 percent.

- Transfers from Zimbabweans abroad to official channels: money transfers through licensed Money Transfer Agencies were guaranteed the higher of the prevailing tender rate or the floor rate of Z\$5,200/US\$1.

- Marginal amendments to the dual interest rate policy: the PSFF is to be capped at Z\$1.5 trillion, extended from mid- to end-2004 (mid-2005 for exporters who account for about one-third of the facility), and the interest rate will be raised to 50 percent in mid-year. A new concessional facility (Z\$165 billion) will be offered to parastatals and local government. The RBZ will offer overnight accommodation at an effective interest rate of "10-20 percent above inflation."

- New subsidy schemes for gold and tobacco: A gold support price of $Z \$ 71,000 / g$ is available to all producers. A subsidy of $Z \$ 750 / \mathrm{kg}$ will be paid for all tobacco delivered to the auction floors.

- Strengthened regulation of the financial sector: (i) boards of banking institutions need to have a majority of independent non-executive directors; (ii) shareholders with a stake over 10 percent cannot be part of the management of a bank or chair the board; and (iii) the ratio of fixed assets to total assets cannot exceed 25 percent. 
resulted in exporters receiving a blend rate ( $1 / 4$ at the surrender rate, $3 / 4$ at the tender rate) that in April was some 40 percent appreciated from the (parallel market) rate at which most foreign transactions took place in late 2003. After the RBZ's April Monetary Policy Statement, the tender rate depreciated somewhat through early May (Figure 3, Appendix II). Inflows of foreign exchange into official channels have strengthened considerably since late 2003.

Figure 3. Zimbabwe: Foreign Exchange Tender
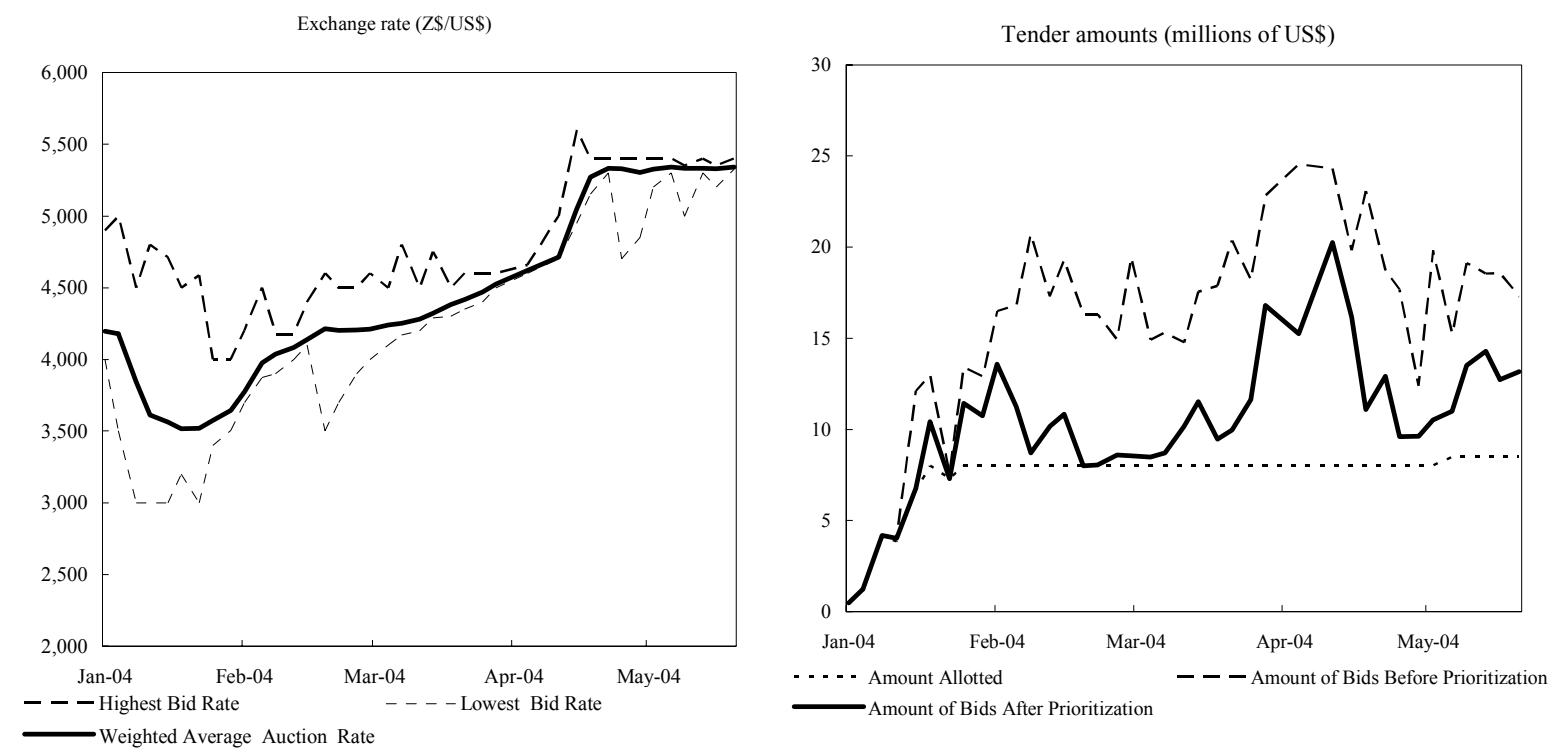

11. Inflation declined in early 2004 as a result of the monetary tightening in 2003 and exchange rates developments. The monthly inflation rate declined to 5 percent in April 2004, from a peak of 34 percent in November 2003, while year-on-year inflation decreased to 505 percent.

12. The external current account deficit narrowed from nearly 8 percent of GDP in 2002 to 6 percent in 2003. An overvalued official exchange rate, onerous surrender requirements, and the decline in agricultural production contributed to a 12 percent decline in recorded exports. At the same time, a critical shortage of foreign exchange in official channels led to a 15 percent decline in imports. ${ }^{4}$ In the absence of foreign financing or usable reserves, the current account deficit was financed by a further accumulation of arrears, which reached US\$2.1 billion, or 44 percent of external debt by year's end.

\footnotetext{
${ }^{4}$ While food imports were mostly financed by the World Food Program, a sharp decline in fuel imports occurred due to NOCZIM's limited access to foreign exchange.
} 
13. The authorities have made modest moves to liberalize the trade regime. In conjunction with the introduction of the VAT in January 2004, the authorities abolished the import duty but retained customs duties and an import surtax on finished goods. As a result, the Fund's trade restrictiveness index rating for Zimbabwe has dropped from 8 to 6 , indicating a trade regime only moderately restrictive. ${ }^{5}$ Intra-regional tariffs were reduced by 5-10 percent in January 2004 for about 3,000 tariff lines with the implementation of Phase II of the liberalization under the Southern African Development Community (SADC) protocol. ${ }^{6}$ Discussions on the rationalization of the customs duties are also ongoing in the contex of the Common Market for Eastern and Southern Africa (COMESA); the authorities are conducting an impact assessment study for the setting up of a customs union, which is expected to be completed by October 2004. Zimbabwe's commitment under COMESA and SADC are in conflict since both regional arrangements aim to become customs unions; it is not clear at this time how this will be resolved.

14. Progress has been limited in implementing other structural reforms. Most price controls were removed after May 2003, and the fuel market was partially liberalized in August. However, civil service reform, enterprise privatizations, and most reforms under the National Economic Revival Program have stalled. The monopoly of the GMB remains, which has led to price distortions and made food shortages worse by discouraging production, preventing private sector imports, and hampering humanitarian assistance. The government announced a major anti-corruption drive in early 2004, mainly targeting individuals who transacted in the parallel market in 2003, but this is seen by most observers as predominantly politically motivated.

\section{Problems relating to the land reform continue to have disruptive effects. ${ }^{7} \mathrm{~A}$}

Presidential Review Committee report of October 2003 implicitly acknowledged the failure to meet the objectives of the fast-track land reform program (FTLRP) launched in 2000, the difficulties encountered in its implementation, and the economic disruption it created. Actual resettlement has fallen significantly short of the government's target and large areas of productive land lay idle. ${ }^{8}$ In addition, the weak know-how of new farmers, the destruction of infrastructure, uncertainty about property rights, and input shortages have lowered productivity, compounding the impact on agricultural production. Moreover, despite the official conclusion of the FTLRP in August 2003, farm acquisitions by the government have

\footnotetext{
${ }^{5}$ Import duties averaged 13.1 percent, customs duties 17.5 percent and the surtax 2.2 percent.

${ }^{6}$ Tariff reductions apply to goods meeting SADC rules of origin. The authorities were unable to provide estimates of the impact of these changes on the average tariff rate.

${ }^{7}$ See Box 4 of the IMF Country Report 03/224 for background.

${ }^{8}$ Actual resettlement (134,452 households and 6.4 million ha) fell short of the government's earlier claims $(350,000$ families and 11 million ha).
} 
reportedly continued, and the government's powers to take over remaining privately-owned land as well as farm equipment were expanded in late 2003/early 2004. Independent reports estimate unemployed former farm workers and their families at 1 million people (8-9 percent of the population).

\section{Policy Discussions}

16. The policy discussions focused on stabilizing the economy and restarting growth. The mission urged the authorities to proceed with a sustained tightening of financial policies and more determined action on the exchange system. While welcoming some of the policy steps taken since late 2003, including the RBZ's efforts to strengthen its supervision of financial institutions, the mission indicated that stronger policies and better cooperation between the MFED and RBZ were necessary to improve the economic situation. Furthermore, tackling Zimbabwe's difficult underlying structural issues, most notably those related to property rights in agriculture, was essential to improve agricultural production, food supply and exports, and to restore investor confidence.

\section{A. Fiscal Policy}

17. Fiscal policy needs to be strengthened urgently to assist in bringing down inflation, while protecting social spending. The mission argued that, in order to support the RBZ's efforts to lower monetary growth, the fiscal stance for 2004 should be tightened to the extent possible, given the remaining timeframe and the need to address social needs. The budget implied a deterioration in the primary balance by 4 percentage points of GDP from the small surplus achieved in 2003. In staff's view, the authorities should instead make efforts to increase the primary surplus to allow room for the increase in interest payments that would result from higher, market-determined, interest rates on government debt consistent with a tighter monetary policy.

18. Determined efforts should be made to enhance fiscal revenue. The mission argued that the unification of the exchange system would facilitate a return of activities to the formal economy, thereby strengthening the tax base, while the exchange rate devaluation would increase customs duties. It also recommended an early move to contemporaneous taxation of profits, and the removal of a number of ad hoc tax exemptions throughout the tax system. At the same time, the mission suggested to review more frequently income tax brackets to avoid bracket creep. While the authorities agreed with the need to strengthen revenue, they thought that time would be needed to reform profit taxation; they also indicated that the surrender exchange rate could not be abolished because of political considerations.

\section{On the expenditure side, the mission urged the authorities to contain} expenditure while protecting the social sectors. Cost-savings should be considered by rationalizing government services, including through further outsourcing, and limiting nonessential spending. In addition, the authorities should resist the pressures to award wage increases beyond what is envisaged in the budget if inflation developments are in line with budget projections. Furthermore, the mission recommended that the authorities seek early 
international assistance to avert large-scale demands on the budget if the 2004 harvest fell short of food requirements. The staff welcomed the introduction of enhanced expenditure monitoring and control mechanisms. The authorities appreciated these suggestions, but indicated that they had no immediate intention to revise the 2004 budget and had no specific comments on social spending. Regarding the food situation, the government in May canceled a joint crop assessment with international partners and is reportedly making arrangements for grain imports.

\section{B. Monetary Policy}

20. The current dual interest rate policy has resulted in serious distortions in the economy. Low interest lending has contributed to unduly high rates of monetary growth and inflation, and there is no evidence that such lending has stimulated production in the aggregate. Negative real interest rates have eroded savings and undermined the health of the financial system, especially of institutional investors required to hold government paper with an effective yield of 150 percent.

21. Monetary policy should focus more consistently on taming inflation. The mission stressed the need to review the structure of interest rates to avoid an excessive toll on the banking system and bring prospective borrowing costs for the government to more realistic levels. In addition, the mission noted that sharply expanded lending through the concessional facilities in early 2004 had eroded monetary control. ${ }^{9}$ The authorities acknowledged this and indicated their intention to cap the concessional facilities at their end-March level of about $\mathrm{Z} \$ 1.5$ trillion (equivalent to two-thirds of outstanding bank credit to the private sector) and to abolish them by the end of the year. Subsequently, the authorities raised the interest rate on these loans from 30 to 50 percent (from July 2004) but, at the same time, they extended the loans made to exporters (about $1 / 3$ of the concessional facilities) through mid-2005 and created new concessional facilities.

\section{The mission welcomed the RBZ's efforts to strengthen its supervision of}

financial institutions, in particular the transfer of bank licensing authority from the MFED to the RBZ. Higher interest rates have begun to put a strain on the banking system, and loan performance is likely to deteriorate in the future as financial policies are tightened (Box 3). The mission and the authorities agreed on the need to monitor provisioning and capital adequacy on a continuous basis, and to enforce prudential norms. In this regard, the mission supported some decisive steps taken by the RBZ in recent months (Box 2) and urged the RBZ to resolve the situation of nonviable institutions. The RBZ indicated a need for technical assistance in these areas.

\footnotetext{
${ }^{9}$ About half of the PSFF was financed by a drawdown in statutory reserves, the other half through direct loans from the RBZ to the banking sector.
} 


\section{Box 3. Banking System Vulnerabilities}

The size of Zimbabwe's banking system in real terms has declined significantly in the last few years (assets fell by 40 percent in real terms in 2003). At end-2003, total assets and deposits of the banking system amounted to roughly 50 and 23 percent of GDP, respectively. Most banks are in local private hands, but some of the largest and oldest banks are foreign owned.

Zimbabwean banks continue to show remarkable resilience in the face of adverse macroeconomic developments (Table 4). Nonperforming loan (NPL) ratios are low (less than 5 percent at end-2003) reflecting largely the negative real interest rates, and most banks report capital adequacy ratios exceeding the 10 percent requirement. Cost-to-income ratios are low by international standards, and most banks reported profits in 2003. Profitability mainly reflects high interest margins, as most banks continue to pay low interest rates on deposits.

The tightening of monetary policy in December 2003 caused some liquidity problems. In early 2004, the RBZ took some decisive steps to deal with a few small insolvent financial institutions by closing them or placing them under curatorship. However, the liquidity support provided was large and dear, weakening monetary control and potentially worsening the underlying problems. A few other banks continue to have liquidity problems, and appropriate mechanisms need to be put in place to deal with them through recapitalization or closure.

Systemic problems in the banking sector in the next 6-12 months cannot be ruled out. Loan performance is likely to deteriorate if the concessional facilities are curtailed and the general interest rate structure is rationalized. These pressures will need to be monitored carefully, and the RBZ should be ready to deal with possible failures of individual institutions and avoid systemic risks. In particular, it is essential that provisioning and capital adequacy be monitored on a continuous basis, and prudential norms enforced.

Corporate governance problems in the banking sector are severe. The RBZ indicated that lending tends to be concentrated to a few insiders and associated groups of companies, and that interference of large shareholders with management is common. Some steps were taken by the RBZ in recent months to address these problems, which are detailed in Box 2. However, further actions are needed. Moreover, the staffing of the Banking Supervision Department of the RBZ is not sufficient, and supervisors need better training.

Stress tests indicate that the Zimbabwean banking system is most vulnerable to credit risk (Table 5) but is practically immune to changes in the exchange rate, as net open positions in foreign exchange are small. 


\section{Exchange Regime, Price Controls and Regulation}

23. Decisive exchange rate action is necessary to reinvigorate exports and contain import demand. The mission welcomed the move of customs valuation to the tender rate, but argued that keeping the surrender requirement at an artificially low exchange rate imposed a heavy tax on exporters. As interim steps to a unified and market-determined exchange rate, the mission suggested to use the tender mechanism more vigorously, abolish the surrender requirement, the preferential price granted to small gold miners, and the 21-day limit on the use of foreign currency accounts, ${ }^{10}$ and allow the parallel foreign exchange market to function as a pressure valve. The authorities agreed with the thrust of the staff's recommendations for the medium term, but felt that in the short run export incentives should be provided through ad-hoc support schemes. In April, they implemented some of the staff's suggestions (unification of gold price, extension of FCA retention period, and some depreciation of the tender exchange rate); at the same time, however, they introduced a new subsidy for tobacco growers and increased tax credits for exports.

24. The new tender system has added two multiple currency practices (MCP) to the two existing ones. This is because (i) the rates at which successful bidders are sold foreign exchange at the same tender can differ by more than two percent, and (ii) the rate used to pay exporters for tendered foreign exchange (weighted average rate at the tender) can also differ from the successful bids rates by more than two percent at any tender. The authorities do not intend to remove these MCPs.

25. The mission welcomed the elimination of most price controls in mid-2003, which increased supplies in the official market and enhanced fiscal revenue. It argued that rolling back remaining price controls, unduly restrictive regulations, and government intervention in the economy would limit the scope for rent-seeking behavior and corruption. The authorities stated they were determined to vigorously pursue the new anti-corruption drive, mainly by pursuing individuals who have dealt in the parallel market. While they agreed with the mission on the need to focus on the underlying causes rather than the symptoms of corruption, they indicated no intention to ease the excessive regulations and economic distortions that have given rise to the parallel market.

\section{Other Structural Policies}

26. Structural reforms are needed to raise productivity throughout the economy. The mission argued that the government's intention to promote indigenization throughout the economy should be based on market mechanisms and implemented in an equitable and fully transparent manner and within a clear and stable legal framework. The mission shared the government's intention to proceed with public enterprise commercialization to reduce the

${ }^{10}$ See appendix II for details on the foreign currency retention system. 
fiscal burden arising from enterprises' losses; but it also recommended to resume privatization, supported by appropriate regulatory changes. As in the past, the staff urged the removal of the monopoly of the GMB, which has given rise to serious distortions in the grain market, and recommended better targeting of basic food subsidies to limit their cost and improve their effectiveness. The authorities were of the view that the monopoly of the GMB was instrumental in achieving food security and should be maintained.

27. Problems relating to the land reform should be addressed to halt their disruptive effect on the economy. The new Land Ministry is preparing a computerized cadastre of current occupants of agricultural land to detect unwarranted multiple farm ownerships and correct farm sizes that would be considered excessive. Moreover, the authorities plan to offer 99-year leases or user-permits to farmers, with no provisions for subletting. The authorities indicated their intention to eventually nationalize all the land, including that protected by bilateral investment agreements. In the short run, they intend to implement a "Designated Farm Scheme" through centrally-supported production of wheat and tobacco. The mission noted that continued uncertainty regarding property rights and poor infrastructure will likely to limit the effectiveness of such schemes; also, the non-transferability of land leases/user permits will likely stifle credit access by farmers. More broadly, staff stressed the importance of addressing the issue of property rights in a way that would restore investor confidence, including by observing commitments under bilateral agreements.

28. The mission stressed that rekindling international support and rebuilding investor confidence would require sound economic policies, strengthening the rule of law, addressing governance issues, and reducing corruption. While the authorities accepted the relevance of these suggestions, they argued that Zimbabwe was an economy under siege and international sanctions limited their room for maneuver.

\section{E. Relations with the Fund}

29. The Executive Board will be considering the issue of compulsory withdrawal of Zimbabwe from the Fund. The mission explained to the authorities that Zimbabwe's arrears preclude access to IMF resources. The mission urged the authorities to demonstrate strengthened cooperation by pursuing sound economic policies to address Zimbabwe's serious difficulties and lay the basis for regularizing its overdue obligations. The mission welcomed the authorities' payments of US\$9 million to date in 2004 and their renewed undertaking to make further small payments of US\$1.5 million to the Fund on a quarterly basis, or more frequently if possible, even though this would not stabilize the stock of arrears.

\section{F. Statistical Issues}

30. Zimbabwe's statistical system presents several deficiencies that hamper policy implementation and the surveillance of economic developments (Appendix IV). The authorities agreed that it was important to strengthen the coverage, accuracy and timeliness of economic statistics, which have been adversely affected by insufficient resources devoted to data collection and analysis and high staff turn over. They indicated their intention to 
strengthen the statistical office and set up a working group between MFED and RBZ to address these issues.

\section{G. Medium-Term Outlook}

31. The staff has prepared two illustrative scenarios for 2004. The baseline scenario assumes some further policy adjustments in 2004, but without the rigor of a sustainable antiinflation strategy. In contrast, the adjustment scenario assumes a tightening of policies consistent with the staff's proposals from May 2004 onwards, as described above. In both scenarios inflation would fall from the record high levels of 2003, mostly on account of the better results achieved so far in 2004, and only temporarily in the baseline scenario as pentup import demand eventually will need to be released.

32. The medium-term projections are built on the baseline scenario (Table 7). They assume that after the March 2005 elections the government would undertake a more determined anti-inflation policy, adopting policies similar to those underlying the adjustment scenario projections for 2004. Loose fiscal policy before the elections and the release of pentup pressures in the adjustment period would lead to a depreciation of the exchange rate and would initially push inflation up again in 2005. However, determined financial tightening through higher interest rates and the achievement of fiscal primary surpluses would bring it down steadily to the double-digit range by 2007 . The associated period of high real interest rates would not significantly increase the domestic debt (equivalent to 10 percent of GDP in 2003), as long as new domestic financing requirements would remain modest. ${ }^{11}$ Credit to the private sector, however, would contract significantly in real terms during the first year of the adjustment effort, reflecting the impact of high real interest rates.

33. The medium-term scenario envisages the vigorous implementation of structural reforms, particularly the clarification of property rights in agriculture. With normal weather patterns and a market-determined exchange rate, real GDP growth of at least 45 percent a year could be achieved over the medium term, reflecting a recovery in agriculture, mining and manufacturing. Assuming that progress is made in cooperating with international partners, international support could be restored and external debt, including arrears, restructured in late 2006 under a Paris Club flow rescheduling. The improved policy framework would unlock the external support that is needed to gradually rebuild foreign exchange reserves and to tackle pressing social needs by allowing a gradual loosening of the fiscal stance once inflation is getting under control. The external debt burden would remain high over the medium term because exports would recover only gradually (Tables 8-9).

34. There are significant risks in the short to medium term. Political constraints could lead to a less comprehensive policy adjustment, thus prolonging the economic collapse and

${ }^{11}$ The projections do not take into account the possible need for state-funded recapitalization of banks in case of systemic banking crisis (Box 3). 
re-igniting the acceleration of inflation. Even if the authorities were to adopt a comprehensive policy package, substantial resources will be needed to tackle structural issues, particularly rebuilding agricultural production and dealing with the HIV/AIDS pandemic and the poor state of the health and education system. It will likely take considerable time to rebuild confidence domestically and abroad, and to return the economy to a path of low inflation and sustained growth.

\section{The staff has also undertaken an illustrative debt assessment exercise} (Appendix V). On the basis of projected end-2005 data, staff has simulated the hypothetical full use of Paris Club traditional debt relief mechanisms. ${ }^{12}$ Zimbabwe's remaining external debt would far exceed the thresholds that apply under the enhanced HIPC Initiative.

\section{StafF APPRAISAL}

36. The sharp economic decline that Zimbabwe has experienced in recent years reflects mainly poor policies, including weak financial management, the imposition of controls, and the adverse effects of the government's land reform program. Inclement weather initially also had a negative impact on agricultural production and food security. These problems have been compounded by concerns over governance, respect for the rule of law, and corruption. As a result, business confidence has been seriously undermined, leading to capital flight and emigration. Spillover effects continue to be felt in neighboring countries. The social consequences have been severe, with a sharp deterioration in many social indicators that had been among the best in Africa.

37. The government did not address these problems in 2003. To the contrary, loose financial policies in 2003 led to a rapid increase in inflation to record high levels and put pressure on the parallel market exchange rate. The good budget outcome reflected the beneficial impact of inflation on revenue, while expenditure was held within the nominal budget authorization despite higher-than-budgeted inflation, reducing public spending in real terms. Monetary policy accommodated excessive credit demand at artificially low interest rates, feeding inflation. The parallel foreign exchange market served increasingly as a pressure valve, allowing exporters to remain competitive and allocating foreign exchange among competing import demands.

38. The government's efforts since late $\mathbf{2 0 0 3}$ have focused on tightening the monetary stance. The measures have been successful in bringing down inflation, at least temporarily. However, the social dialogue that started in early 2003 has not been continued, and the government has yet to work out a consistent overall macroeconomic framework that would help guide policy making.

${ }^{12}$ See Table 38 of the statistical appendix for a presentation of Zimbabwe's external debt by creditor. 
39. A decisive fiscal effort is required to help reduce inflation on a sustained basis. Prompt unification of the exchange system and removal of ad hoc tax exemptions would strengthen revenue mobilization. In addition, the government should exercise strict control over the wage bill and non-essential spending, while allowing Treasury bill interest rates to rise and protecting social and infrastructure outlays, including food imports, if necessary.

40. Monetary policy should be tightened on a more sustained basis to consolidate the gains made to date in lowering inflation. At the same time, there is an urgent need to rationalize the interest rate structure and phase out concessional lending in order to contain credit demand and provide a positive real return to savers. This would help contain the impact on prices of a market-based exchange rate unification and of removing remaining price controls. There is also a need to improve the preparation of short-term liquidity forecasts.

41. Efforts should be continued to strengthen financial sector supervision, particularly with regard to provisioning and capital adequacy. The RBZ should be prepared to deal with weak and unsound banks, and reduce systemic risks. Stronger supervision, in particular with regard to provisioning and capital adequacy, will help contain the effects of tighter financial policies and re-instill confidence in the domestic banking system.

42. The foreign exchange system should be unified to reduce distortions and improve external competitiveness. The new foreign exchange tender mechanism has been heavily managed to date. Instead, the exchange rate should be allowed to respond to market forces.

43. Zimbabwe's trade regime should be further liberalized and exchange restrictions removed. Zimbabwe maintains a number of exchange restrictions on the making of payments and transfers for current international transactions and has increased the number of its multiple currency practices subject to approval under Article VIII. In the absence of a timetable for their removal, staff does not recommend their approval.

44. The authorities should urgently address structural impediments to improve food security. The GMB monopoly should be removed and well-targeted basic food subsidies put in place. The government's decision in early May to abort the joint crop assessment was disappointing and left the authorities without a basis for a timely appeal for food aid.

45. Structural policy reforms focusing on increasing production and raising productivity throughout the economy are critical to restart economic growth. Restrictive regulations should be removed to bring more activities into the formal economy, and the government's promotion of indigenization should be based on market principles and implemented in an equitable and fully transparent manner. In addition, the prompt commercialization and eventual privatization of public enterprises, supported by appropriate regulatory changes, would help reduce the fiscal burden on the government and improve service delivery. 
46. Consistent with the aims of their anti-corruption campaign, the authorities should focus more on the root causes of corruption rather than its symptoms. Price distortions, numerous sector-specific incentive programs, and preferential access of a few to cheap foreign exchange distracts from productive activities and provides significant opportunities for rent-seeking behavior.

47. Problems relating to the land reform should be addressed to halt their disruptive effects on the economy. In particular, the clarification of ownership rights is crucial to raising agricultural production and facilitating access to credit for farmers.

48. A successful implementation of the reforms described above requires a resumption of external support, which is currently limited to humanitarian assistance. In this regard, the authorities should seek to normalize relations with external creditors and formulate a plan for the elimination of external payments arrears. Restoring international assistance, attracting foreign investment, and dealing with Zimbabwe's mounting external debt will require, inter alia, the adoption of sound economic policies, stronger governance, and improvements in the rule of law.

49. Efforts should be intensified to address deficiencies in the statistical system that hamper policy implementation and the surveillance of economic developments.

50. It is proposed that the next Article IV Consultation with Zimbabwe be held on the standard 12-month cycle. 
Table 1. Zimbabwe: Selected Economic Indicators, 2000-2004

\begin{tabular}{|c|c|c|c|c|c|c|}
\hline & \multirow[t]{2}{*}{2000} & \multirow[t]{2}{*}{2001} & \multirow[t]{2}{*}{2002} & \multirow{2}{*}{$\begin{array}{c}2003 \\
\text { Est. }\end{array}$} & \multicolumn{2}{|c|}{2004} \\
\hline & & & & & $\begin{array}{l}\text { Baseline } \\
\text { Scenario }\end{array}$ & $\begin{array}{r}\text { Adjustment } \\
\text { Scenario }\end{array}$ \\
\hline \multicolumn{7}{|l|}{ GDP } \\
\hline Real GDP (market prices; percentage change) & -7.9 & -2.8 & -11.1 & -9.3 & -5.2 & -4.2 \\
\hline Real per capita GDP (percentage change) & -7.6 & -2.5 & -10.9 & -9.1 & -4.9 & -4.0 \\
\hline \multicolumn{7}{|l|}{ Savings and investment (percent of GDP) $1 /$} \\
\hline Gross national savings (excluding grants) & 0.4 & -2.8 & -0.7 & -3.0 & -4.6 & -11.8 \\
\hline Gross investment & 0.9 & 2.1 & 2.1 & 1.9 & 3.1 & 3.1 \\
\hline \multicolumn{7}{|l|}{ Prices and interest and exchange rates (percent) } \\
\hline Consumer price inflation (annual average) & 55.9 & 76.7 & 140.0 & 431.7 & 352.6 & 299.6 \\
\hline Consumer price inflation (end of period) & 55.2 & 112.1 & 198.9 & 598.7 & 256.4 & 158.6 \\
\hline 91-day treasury bills (annualized yield; end of period) & 57.8 & 25.9 & 26.6 & 60.7 & 200.0 & 310.0 \\
\hline Real effective exchange rate (percentage change) & 42.7 & 47.6 & 131.5 & 28.7 & $\ldots$ & $\ldots$ \\
\hline \multicolumn{7}{|l|}{ Central government budget (percent of GDP) } \\
\hline Revenue & 26.7 & 24.1 & 25.2 & 23.7 & 25.0 & 27.4 \\
\hline Expenditure and net lending & 48.3 & 33.5 & 29.2 & 24.0 & 34.7 & 35.0 \\
\hline Of which: interest on central government debt & 16.1 & 9.4 & 4.1 & 1.2 & 8.3 & 9.6 \\
\hline Overall balance, commitment basis (excluding grants) & -21.6 & -9.4 & -3.9 & -0.3 & -9.7 & -7.6 \\
\hline Primary balance, excluding grants & -5.4 & 0.0 & 0.2 & 0.8 & -1.4 & 2.0 \\
\hline Overall balance, cash basis (including grants) & -19.7 & -6.8 & -3.1 & -0.2 & -7.3 & -6.0 \\
\hline Domestic financing (including privatization) & 18.8 & 6.7 & 3.3 & 0.2 & 7.3 & 6.0 \\
\hline External financing & 0.8 & 0.1 & -0.1 & 0.0 & 0.0 & 0.0 \\
\hline \multicolumn{7}{|l|}{ Money and credit (percentage change; end of period) } \\
\hline Broad money (M3) & 59.9 & 102.7 & 164.8 & 413.5 & 252.8 & 166.9 \\
\hline Excluding Valuation adjustments & $\ldots$ & & & & 234.9 & 105.3 \\
\hline Domestic credit & 61.5 & 80.3 & 149.2 & 397.6 & 240.1 & 124.2 \\
\hline Of which: credit to the private sector & 38.1 & 68.5 & 183.6 & 522.1 & 195.7 & 73.4 \\
\hline \multicolumn{7}{|l|}{ External trade (percentage change) } \\
\hline Export volume & 6.3 & -21.1 & -13.9 & -17.3 & -11.3 & 1.7 \\
\hline Import volume & 8.5 & -0.9 & 4.6 & -21.5 & -8.5 & 0.4 \\
\hline Terms of trade & 2.5 & -4.4 & 0.5 & -1.7 & -0.3 & -0.3 \\
\hline \multicolumn{7}{|l|}{ Balance of payments (billions of U.S. dollars, unless otherwise indicated) } \\
\hline Exports & 2.20 & 1.58 & 1.40 & 1.23 & 1.13 & 1.29 \\
\hline Imports & -1.91 & -1.79 & -1.92 & -1.63 & -1.55 & -1.70 \\
\hline Current account balance (excluding official transfers) & 0.0 & -0.5 & -0.6 & -0.4 & -0.4 & -0.5 \\
\hline (In percent of GDP at the official exchange rate) $1 /$ & -0.5 & -4.8 & -2.8 & -4.8 & -7.7 & -14.9 \\
\hline (In percent of GDP at world prices) $2 /$ & -0.4 & -5.9 & -7.9 & -6.0 & -6.5 & -6.6 \\
\hline Overall balance & -0.1 & -0.3 & -0.6 & -0.6 & -0.4 & -0.4 \\
\hline \multicolumn{7}{|l|}{ Official reserves (gold valued at market price) } \\
\hline Usable reserves (millions of U.S. dollars; end of period) & 22.1 & 20.0 & 15.1 & 18.3 & 24.0 & 42.5 \\
\hline (months of imports of goods and services) & 0.1 & 0.1 & 0.1 & 0.1 & 0.2 & 0.2 \\
\hline (percent of reserve money) & 187.0 & 54.1 & 0.6 & 2.1 & 5.1 & 28.1 \\
\hline \multicolumn{7}{|l|}{ External debt and arrears (including private debt) } \\
\hline Total external debt (percent of GDP at world prices; end of period) 2/ & 47.0 & 45.3 & 57.0 & 68.4 & 76.3 & 75.6 \\
\hline Of which: total external arrears & 4.7 & 9.5 & 19.8 & 30.2 & 38.0 & 37.7 \\
\hline Debt service (percent of exports of goods and services) & 22.9 & 31.4 & 35.1 & 35.4 & 35.3 & 30.8 \\
\hline \multicolumn{7}{|l|}{ Social indicators } \\
\hline Life expectancy at birth (in years) & 39.9 & 39.5 & 39.0 & $\ldots$ & $\ldots$ & $\ldots$ \\
\hline Infant mortality rate (per 1,000 live births) & 73.0 & 76.0 & 76.0 & $\ldots$ & $\ldots$ & $\ldots$ \\
\hline Adult illiteracy rate (percent of adults ages 15 and above) & 11.3 & 10.7 & 10.0 & $\ldots$ & $\ldots$ & $\ldots$ \\
\hline HIV/AIDS adult infection rate (percent of adults ages 15-49) & $\ldots$ & $\ldots$ & $\ldots$ & 24.6 & $\ldots$ & $\ldots$ \\
\hline
\end{tabular}

Sources: Zimbabwean authorities; World Bank, World Development Indicators 2003; and staff estimates and projections.

1/ Foreign currency units are converted into Zimbabwe dollars at the official exchange rate.

2/ GDP at world prices using real GDP growth and trading partner countries' inflation (base year is 1996). 


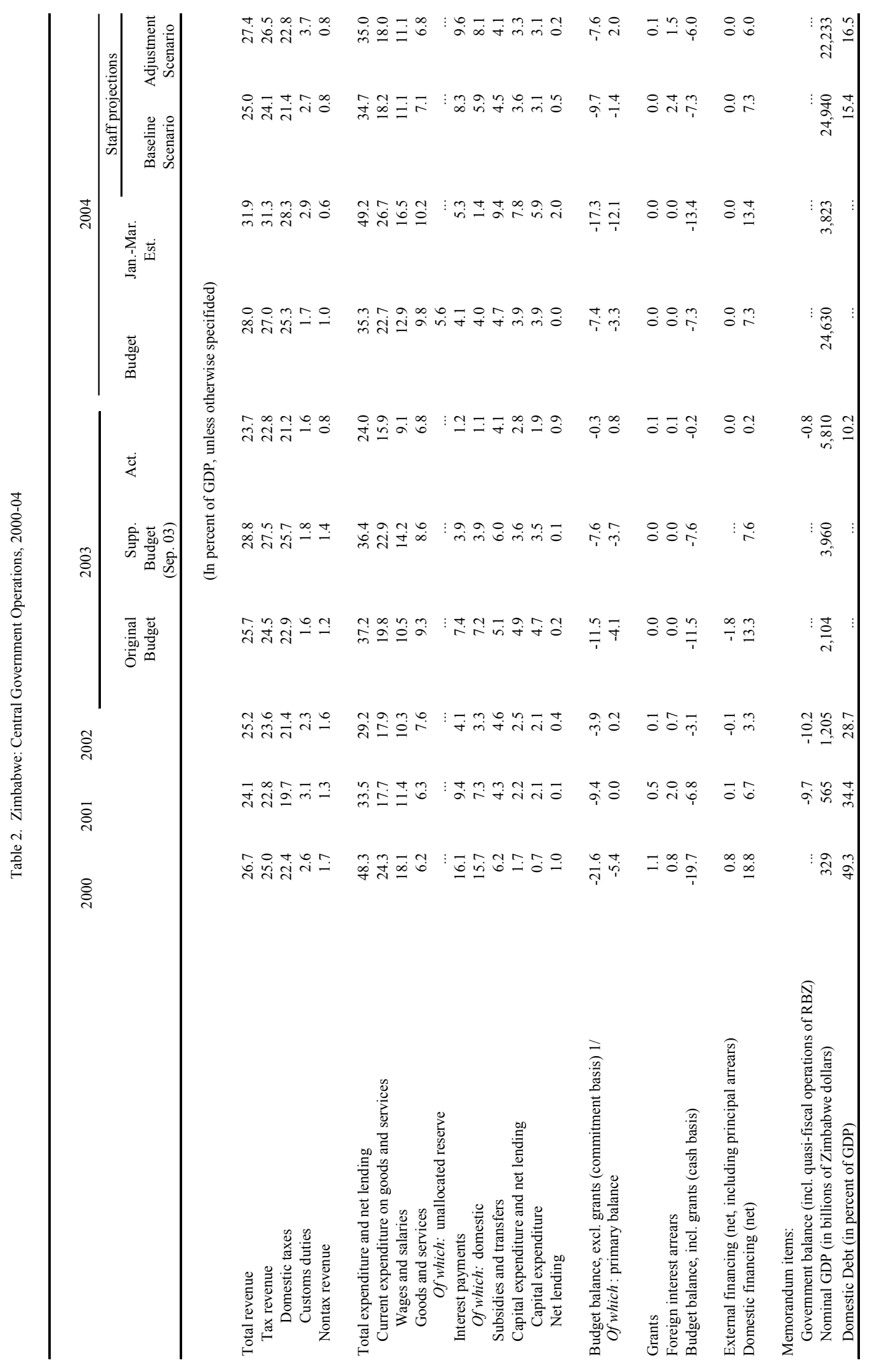




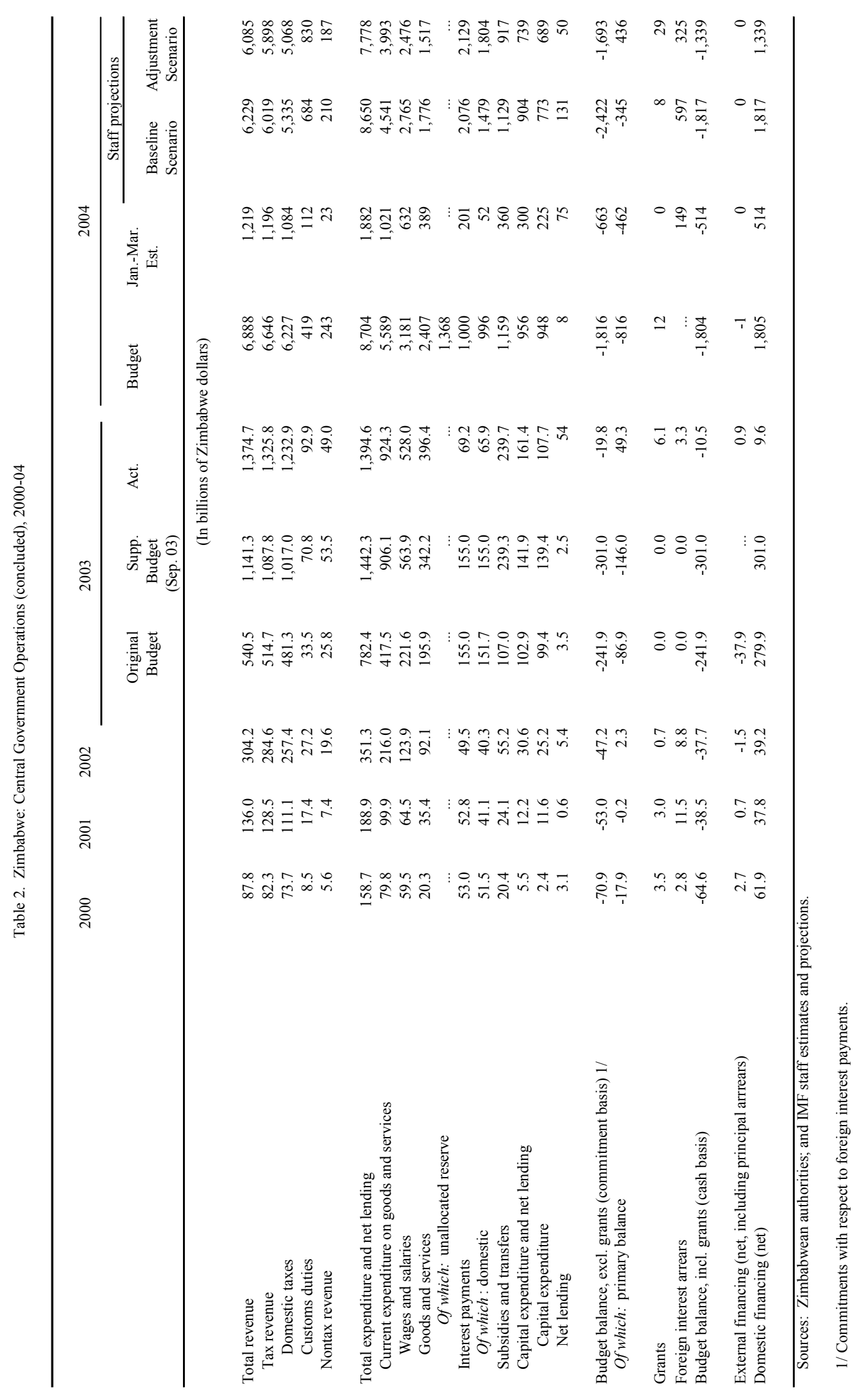


Table 3. Zimbabwe: Monetary Survey, 2000-2004

\begin{tabular}{|c|c|c|c|c|c|c|c|c|c|}
\hline & \multirow[t]{2}{*}{2000} & \multirow[t]{2}{*}{2001} & \multirow[t]{2}{*}{2002} & \multicolumn{4}{|c|}{2003} & \multicolumn{2}{|c|}{2004} \\
\hline & & & & Mar. & Jun. & Sep. & Dec. & $\begin{array}{l}\text { Baseline } \\
\text { Scenario }\end{array}$ & $\begin{array}{l}\text { Adjustment } \\
\text { Scenario }\end{array}$ \\
\hline & \multicolumn{9}{|c|}{ (Annual percentage change) } \\
\hline Reserve money & 16.0 & 164.9 & 171.2 & 295.2 & 408.5 & 356.8 & 394.8 & 266.6 & 150.9 \\
\hline Broad money (M3) & 59.9 & 102.7 & 164.8 & 206.7 & 275.8 & 418.7 & 413.5 & 252.8 & 166.9 \\
\hline Currency & 37.3 & 161.1 & 215.8 & 215.8 & 265.5 & 375.0 & 456.0 & 218.0 & 134.4 \\
\hline \multirow[t]{2}{*}{ Deposits } & 62.2 & 97.6 & 158.9 & 205.7 & 277.2 & 424.1 & 407.6 & 258.1 & 171.9 \\
\hline & \multicolumn{9}{|c|}{ (Contribution to reserve money growth, in percent) } \\
\hline \multicolumn{10}{|l|}{ Monetary authorities } \\
\hline Net foreign assets of reserve bank $1 /$ & 1.8 & -7.2 & -3.0 & -17.1 & -303.0 & -195.0 & -153.7 & -191.0 & -416.4 \\
\hline Excluding valuation adjustments $2 /$ & $\ldots$ & $\ldots$ & $\ldots$ & -8.9 & -6.4 & 0.9 & -1.0 & 0.0 & 0.2 \\
\hline Net domestic assets of reserve bank & 14.2 & 172.1 & 174.2 & 312.2 & 711.5 & 551.8 & 548.5 & 457.7 & 567.3 \\
\hline Excluding valuation adjustments $2 /$ & $\ldots$ & $\ldots$ & $\ldots$ & 323.1 & 439.8 & 416.6 & 469.2 & 266.6 & 150.7 \\
\hline Credit to government (net) & 3.9 & 111.2 & 127.3 & 287.2 & 455.5 & 292.9 & 167.9 & -10.3 & -32.8 \\
\hline Credit to non-financial public enterprises & 0.0 & 6.7 & -2.5 & -0.9 & -1.1 & -0.5 & -0.4 & 0.0 & 0.0 \\
\hline Credit to private sector & 26.6 & 71.1 & 66.5 & 52.7 & 41.6 & 134.0 & 246.9 & 419.3 & 438.2 \\
\hline Excluding valuation adjustments $2 /$ & $\ldots$ & $\ldots$ & $\ldots$ & 44.5 & 35.8 & 117.6 & 245.4 & 417.3 & 433.5 \\
\hline Other items (net) & -16.3 & -16.9 & -17.1 & -26.7 & 215.5 & 125.5 & 134.1 & 189.1 & 412.0 \\
\hline Excluding valuation adjustments 2/ & $\cdots$ & $\ldots$ & $\ldots$ & -26.7 & -75.2 & -54.0 & -17.1 & 0.0 & 0.0 \\
\hline Reserve money & 16.0 & 164.9 & 171.2 & 295.2 & 408.5 & 356.8 & 394.8 & 266.6 & 150.9 \\
\hline Currency outside banks & 14.4 & 73.8 & 97.4 & 131.7 & 202.1 & 187.2 & 239.6 & 128.7 & 79.4 \\
\hline Nonbank deposits & -0.5 & 0.2 & 0.9 & 6.2 & 5.8 & -4.1 & 4.4 & 3.2 & 2.8 \\
\hline Other banking inst. reserves & 0.5 & 2.9 & 2.6 & 3.2 & 1.3 & 7.0 & 4.9 & 4.5 & 2.3 \\
\hline Deposit money bank (DMB) reserves & 1.7 & 88.0 & 70.3 & 154.1 & 199.3 & 166.7 & 145.9 & 130.2 & 66.4 \\
\hline Monetary survey & \multicolumn{9}{|c|}{ (Contribution to broad money growth, in percent) } \\
\hline Net foreign assets & 4.4 & -0.2 & 0.0 & 13.3 & -25.8 & -15.1 & -20.7 & -36.5 & -76.3 \\
\hline Excluding valuation adjustments $2 /$ & $\ldots$ & $\ldots$ & $\ldots$ & -1.5 & -0.2 & 0.4 & 0.4 & -0.1 & -0.1 \\
\hline Net domestic assets & 55.5 & 102.9 & 164.8 & 193.5 & 301.7 & 433.8 & 434.2 & 289.2 & 243.2 \\
\hline Domestic credit & 74.8 & 98.7 & 163.0 & 188.9 & 276.5 & 383.5 & 408.9 & 239.2 & 123.7 \\
\hline Claims on government (net) & 35.5 & 40.1 & 41.4 & 42.4 & 76.4 & 73.9 & 44.4 & 64.1 & 47.6 \\
\hline Claims on nonfinancial public enterprises & 6.2 & 9.0 & 11.3 & 13.3 & 19.8 & 25.1 & 26.5 & 21.7 & 18.6 \\
\hline Claims on private sector & 33.2 & 49.6 & 110.4 & 133.1 & 180.3 & 284.5 & 338.0 & 153.4 & 57.5 \\
\hline Other items (net) & -19.4 & 4.3 & 1.8 & 4.6 & 25.1 & 50.3 & 25.3 & 50.0 & 119.5 \\
\hline Excluding valuation adjustments 2/ & $\ldots$ & $\ldots$ & $\ldots$ & 2.8 & -21.7 & 10.8 & -13.8 & -8.6 & -8.6 \\
\hline Broad money (M3) & 59.9 & 102.7 & 164.8 & 206.7 & 275.8 & 418.7 & 413.5 & 252.8 & 166.9 \\
\hline Excıaing valuaton aajustments & & & & & & & & 234.9 & 105.3 \\
\hline Currency & 3.5 & 12.9 & 22.3 & 22.5 & 30.8 & 41.6 & 56.3 & 29.1 & 18.0 \\
\hline Deposits & 56.4 & 89.8 & 142.4 & 184.3 & 245.0 & 377.0 & 357.2 & 223.6 & 149.0 \\
\hline & \multicolumn{9}{|c|}{ (Ratios, unless specified otherwise) } \\
\hline \multicolumn{10}{|l|}{ Memorandum items: } \\
\hline Currency-deposit ratio & 8.7 & 11.5 & 14.1 & 12.0 & 12.7 & 11.3 & 15.4 & 13.7 & 13.3 \\
\hline Reserves-deposit ratio & 10.3 & 14.0 & 12.6 & 12.2 & 10.2 & 10.3 & 10.5 & 12.8 & 10.5 \\
\hline Money multiplier (M3/reserve money) & 3.1 & 3.1 & 3.3 & 3.3 & 4.9 & 5.1 & 4.4 & 4.3 & 4.7 \\
\hline Velocity (GDP/period-average M3) & 3.4 & 3.2 & 2.8 & 3.4 & 3.3 & 2.6 & 3.0 & 3.4 & 3.7 \\
\hline CPI inflation (12 months end-of-period; percent) & 55.2 & 112.1 & 198.9 & 228.0 & 364.5 & 455.6 & 598.7 & 256.4 & 158.6 \\
\hline Private sector credit growth (12 months; percent) & 38.1 & 68.5 & 183.6 & 209.6 & 256.7 & 491.4 & 522.1 & 195.7 & 73.4 \\
\hline Real private sector credit growth (12 months percentage change) & -11.0 & -20.6 & -5.1 & -5.6 & -23.2 & 6.4 & -11.0 & -17.0 & -33.0 \\
\hline
\end{tabular}


Table 3. Zimbabwe: Monetary Survey, 2000-2004 (concluded)

\begin{tabular}{|c|c|c|c|c|c|c|c|c|c|}
\hline & \multirow[t]{2}{*}{2000} & \multirow[t]{2}{*}{2001} & \multirow[t]{2}{*}{2002} & \multicolumn{4}{|c|}{2003} & \multicolumn{2}{|c|}{2004} \\
\hline & & & & Mar. & Jun. & Sep. & Dec. & $\begin{array}{l}\text { Baseline } \\
\text { Scenario }\end{array}$ & $\begin{array}{l}\text { Adjustment } \\
\text { Scenario }\end{array}$ \\
\hline Monetary authorities & \multicolumn{9}{|c|}{ (In billions of Zimbabwe dollars) } \\
\hline Net foreign assets of reserve bank 1 / & -11.5 & -13.0 & -14.7 & -22.8 & -171.4 & -209.3 & -242.5 & $-1,644$ & $-3,297$ \\
\hline Of which: Valuation effect (est.) 2/ & $\ldots$ & $\ldots$ & $\ldots$ & -4.0 & -152.6 & -195.3 & -226.3 & $-1,628$ & $-3,282$ \\
\hline Net domestic assets of reserve bank & 32.2 & 67.7 & 162.9 & 216.6 & 433.1 & 664.9 & 976.1 & 4,333 & 5,138 \\
\hline Credit to government (net) & 4.6 & 27.6 & 97.2 & 169.3 & 264.2 & 351.8 & 346.1 & 270 & 106 \\
\hline Of which: exchange rate subsidy(est.) & $\ldots$ & $\ldots$ & $\ldots$ & $\ldots$ & 13.3 & 28.8 & 32.5 & $\ldots$ & $\ldots$ \\
\hline Credit to nonfinancial public enterprises & 0.7 & 2.0 & 0.6 & 0.1 & 0.1 & 0.1 & 0.1 & 0 & 0 \\
\hline Credit to private sector & 16.3 & 31.0 & 67.4 & 52.0 & 52.0 & 162.2 & 433.4 & 3,509 & 3,648 \\
\hline Credit to deposit money banks & 14.3 & 28.7 & 64.7 & 49.2 & 45.2 & 154.7 & 426.2 & 3,478 & 3,620 \\
\hline Of which: Valuation effect (est.) 2/ & $\ldots$ & $\ldots$ & $\ldots$ & 4.0 & 3.0 & 16.4 & 2.3 & 17 & 36 \\
\hline Credit to nonbank private sector & 2.0 & 2.3 & 2.7 & 2.7 & 6.8 & 7.5 & 7.2 & 31 & 27 \\
\hline RBZ bills & & & & & & & & $-1,029$ & $-1,834$ \\
\hline Other items net & 10.6 & 7.1 & -2.3 & -4.8 & 116.9 & 150.8 & 196.5 & 1,584 & 3,218 \\
\hline Of which: Valuation effect (est.) 2/ & $\ldots$ & $\ldots$ & $\ldots$ & 0.0 & 149.6 & 178.9 & 224.0 & 1,611 & 3,246 \\
\hline \multicolumn{10}{|l|}{ RBZ bills } \\
\hline Reserve money & 20.6 & 54.7 & 148.2 & 193.8 & 261.7 & 455.6 & 733.5 & 2,690 & 1,840 \\
\hline Currency outside banks & 9.5 & 24.7 & 77.9 & 94.5 & 143.2 & 236.5 & 433.2 & 1,377 & 1,015 \\
\hline Nonbank deposits & 0.1 & 0.2 & 0.7 & 3.5 & 3.4 & 3.1 & 7.2 & 31 & 28 \\
\hline Other banking institution reserves & 0.7 & 1.3 & 2.7 & 2.8 & 1.8 & 8.5 & 9.9 & 43 & 27 \\
\hline Deposit money bank reserves & 10.4 & 28.6 & 67.0 & 93.1 & 113.3 & 207.4 & 283.3 & 1,238 & 771 \\
\hline \multicolumn{10}{|l|}{ Deposit money banks and other banking institutions } \\
\hline Net foreign assets & -0.5 & 0.7 & 2.3 & 49.9 & 70.7 & 134.5 & 99.7 & 319 & 683 \\
\hline Of which: Valuation effect (est.) 2/ & $\ldots$ & $\ldots$ & $\ldots$ & 46.5 & 66.0 & 125.5 & 93.1 & 316 & 680 \\
\hline Reserves & 10.4 & 31.9 & 91.5 & 128.4 & 152.5 & 335.2 & 620.3 & 2,311 & 2,632 \\
\hline Net credit from the reserve bank & -14.7 & -19.1 & -61.2 & -48.7 & -40.4 & -162.3 & -473.9 & $-3,478$ & $-3,620$ \\
\hline Of which: Valuation effect (est.) 2/ & $\ldots$ & $\ldots$ & $\ldots$ & -4.0 & -3.0 & -16.4 & -2.3 & -17 & -36 \\
\hline Total credit & 137.1 & 228.5 & 548.4 & 687.4 & $1,055.1$ & $1,825.2$ & $2,875.6$ & 10,680 & 7,105 \\
\hline Credit to government (net) & 43.6 & 67.8 & 96.7 & 63.8 & 126.5 & 150.0 & 128.0 & 2,280 & 1,912 \\
\hline Credit to nonfinancial public enterprises & 8.5 & 17.7 & 45.9 & 61.8 & 88.9 & 147.0 & 213.9 & 918 & 815 \\
\hline Credit to private sector & 84.9 & 143.1 & 405.8 & 561.9 & 839.8 & $1,528.2$ & $2,533.7$ & 7,481 & 4,378 \\
\hline Of which: Valuation effect (est.) 2/ & $\ldots$ & & & 41.7 & 29.3 & 27.7 & 31.6 & 232 & 499 \\
\hline Other items (net) & -24.3 & -28.6 & -28.6 & -34.1 & -114.7 & -46.3 & -321.9 & 191 & 807 \\
\hline Of which: Valuation effect (est.) 2/ & $\ldots$ & $\ldots$ & $\ldots$ & 5.3 & 8.7 & -1.7 & 22.9 & 536 & 1,152 \\
\hline Total deposits & 108.0 & 213.5 & 552.4 & 782.9 & $1,123.2$ & $2,086.3$ & $2,799.9$ & 10,022 & 7,606 \\
\hline Of which: Valuation effect (est.) 2/ & $\ldots$ & $\ldots$ & $\ldots$ & 89.6 & 101.0 & 135.2 & 145.3 & 1,067 & 2,294 \\
\hline \multicolumn{10}{|l|}{ Monetary survey } \\
\hline Net foreign assets & -12.0 & -12.3 & -12.4 & 27.1 & -100.7 & -74.8 & -142.8 & $-1,325$ & $-2,614$ \\
\hline Of which: Valuation effect (est.) 2/ & $\ldots$ & $\ldots$ & $\ldots$ & 42.5 & -86.6 & -69.8 & -133.3 & $-1,312$ & $-2,602$ \\
\hline Net domestic assets & 129.6 & 250.6 & 643.3 & 853.8 & $1,370.5$ & $2,400.7$ & $3,383.1$ & 12,755 & 11,263 \\
\hline Domestic credit & 144.4 & 260.4 & 648.9 & 859.6 & $1,326.2$ & $2,184.6$ & $3,229.0$ & 10,981 & 7,238 \\
\hline Claims on government (net) $3 /$ & 48.3 & 95.3 & 193.9 & 233.1 & 390.7 & 501.8 & 474.1 & 2,550 & 2,018 \\
\hline Claims on nonfinancial public enterprises & 9.2 & 19.7 & 46.5 & 61.9 & 89.0 & 147.1 & 214.0 & 918 & 815 \\
\hline Claims on private sector & 87.0 & 145.3 & 408.4 & 564.6 & 846.6 & $1,535.6$ & 2,541 & 7,512 & 4,405 \\
\hline Of which: Valuation effect (est.) 2/ & $\ldots$ & $\ldots$ & $\ldots$ & 41.7 & 29.3 & 27.7 & 31.6 & 232 & 499 \\
\hline Other items (net) & -14.8 & -9.8 & -5.6 & -5.8 & 44.4 & 216.1 & 154.0 & 1,774 & 4,025 \\
\hline Of which: Valuation effect (est.) 2/ & $\ldots$ & $\ldots$ & $\ldots$ & 5.3 & 158.4 & 177.2 & 247.0 & 2,147 & 4,398 \\
\hline Broad money (M3) & 117.6 & 238.3 & 631.0 & 880.9 & $1,269.9$ & $2,325.9$ & $3,240.3$ & 11,431 & 8,649 \\
\hline Currency & 9.5 & 24.7 & 77.9 & 94.5 & 143.2 & 236.5 & 433.2 & 1,377 & 1,015 \\
\hline Deposits & 108.1 & 213.6 & 553.1 & 786.4 & $1,126.6$ & $2,089.4$ & $2,807.1$ & 10,053 & 7,634 \\
\hline Of which: Valuation effect (est.) 2/ & $\ldots$ & $\ldots$ & $\ldots$ & 89.6 & 101.0 & 135.2 & 145.3 & 1,067 & 2,294 \\
\hline & \multicolumn{9}{|c|}{ (In millions of U.S. dollars) } \\
\hline Memorandum items: & & & & & & & & & \\
\hline Net foreign assets of reserve bank & -210 & -237 & -267 & $\ldots$ & -208 & -254 & -294 & -288 & -270 \\
\hline Of which: gross usable reserves & 22 & 20 & 15 & $\ldots$ & $\ldots$ & $\ldots$ & 18 & $\ldots$ & $\ldots$ \\
\hline Net foreign assets of banking system & -9 & 13 & 42 & & 86 & 163 & 121 & 56 & 56 \\
\hline
\end{tabular}

1/ Reserve Bank of Zimbabwe's net foreign assets and net domestic assets have been adjusted for memorandum of deposits. Includes valuation effects.

2/ At an exchange rate of $Z \$ 55$ per US\$1.

$3 /$ Credit to the government differs from the fiscal table as it includes accrued interest on domestic government debt, while domestic interest in the fiscal table is recorded as it falls due. 
Table 4. Zimbabwe: Financial Soundness Indicators for the Banking Sector, December 2003

(In percent, unless otherwise indicated)

\begin{tabular}{|c|c|c|c|c|c|}
\hline & $\begin{array}{c}\text { All } \\
\text { Banks }\end{array}$ & $\begin{array}{l}\text { Banks rated } \\
\text { "1",1/ }\end{array}$ & $\begin{array}{l}\text { Banks rated } \\
\text { "2" }\end{array}$ & $\begin{array}{c}\text { Banks rated } \\
\text { "3" }\end{array}$ & $\begin{array}{l}\text { Banks rated } \\
\text { "4" or "5" }\end{array}$ \\
\hline Number of banks & 40 & 10 & 14 & 8 & 8 \\
\hline Total assets (Z\$ billion) & $6,000.6$ & $2,437.9$ & $1,725.6$ & 821.0 & $1,016.1$ \\
\hline Total capital ( $Z \$$ billion) & 510.6 & 295.5 & 103.9 & 68.3 & 42.9 \\
\hline Market share of total assets & 100.0 & 40.6 & 28.8 & 13.7 & 16.9 \\
\hline \multicolumn{6}{|l|}{ Capital Adequacy } \\
\hline Capital to risk-weighted assets & 16.2 & 22.0 & 13.4 & 15.3 & 7.2 \\
\hline Tier I capital to risk-weighted assets & 13.9 & 18.3 & 13.3 & 12.8 & 5.7 \\
\hline Capital to assets & 8.5 & 12.1 & 6.0 & 8.3 & 4.2 \\
\hline \multicolumn{6}{|l|}{ Asset composition and quality } \\
\hline FX loans to total loans & 2.0 & 4.4 & 0.1 & 0.0 & 0.0 \\
\hline NPLs to gross loans & 4.7 & 4.4 & 5.9 & 3.4 & 3.8 \\
\hline Total provisions to NPLs & 70.1 & 63.9 & 79.2 & 66.8 & 63.5 \\
\hline NPLs net of specific provisions to capital & 13.0 & 9.5 & 22.4 & 7.6 & 22.1 \\
\hline $\begin{array}{l}\text { Deposits of government and state enterprises to } \\
\text { total deposits }\end{array}$ & 7.3 & 0.6 & 14.1 & 0.3 & 21.6 \\
\hline \multicolumn{6}{|l|}{ Earnings and Profitability } \\
\hline Return on Asset (ROA) ${ }^{2 /}$ & 6.7 & 9.1 & 5.6 & 4.5 & 4.5 \\
\hline Return on Equity (ROE) $)^{2 /}$ & 114.8 & 111.5 & 137.7 & 76.5 & 143.0 \\
\hline Interest income to noninterest income & 529.1 & 351.6 & 985.4 & 488.3 & 644.6 \\
\hline Net interest income to interest expenses & 65.1 & 196.5 & 49.8 & 26.2 & 21.4 \\
\hline Noninterest expenses to gross income & 21.5 & 31.0 & 16.7 & 18.5 & 13.1 \\
\hline Personnel expenses to gross income & 9.2 & 13.5 & 8.0 & 7.0 & 4.5 \\
\hline \multicolumn{6}{|l|}{ Liquidity } \\
\hline Liquid assets to total assets & 15.0 & 17.1 & 21.8 & 6.8 & 5.0 \\
\hline Liquid assets to demand deposits & 55.1 & 44.6 & 127.3 & 20.1 & 40.1 \\
\hline Total (non-interbank) loans to customer deposits & 66.8 & 67.0 & 74.5 & 43.0 & 74.9 \\
\hline FX deposits to total deposits & 5.6 & 6.1 & 1.9 & 16.2 & 1.1 \\
\hline \multicolumn{6}{|l|}{ Sensitivity to market risk } \\
\hline Net open positions in FX to capital & -2.6 & -1.8 & -5.2 & -7.0 & 4.8 \\
\hline
\end{tabular}

Source: Reserve Bank of Zimbabwe.

1/ Ratings refer to CAMEL ratings by the RBZ.

2/ ROA and ROE are calculated as a ratio of profit for 2003 to assets and equity, respectively, for end-2003.

Given the rate of inflation in 2003, they are likely to be overestimates of the true ROA and ROE by roughly a factor of 2 . 
Table 5. Zimbabwe: Summary Results of Stress Tests, end-December 2003

\begin{tabular}{|c|c|c|c|c|c|c|c|}
\hline & $\begin{array}{c}\text { Banking } \\
\text { System }\end{array}$ & $\begin{array}{c}\text { Banks rated } \\
\text { "1"1/ }\end{array}$ & $\begin{array}{c}\text { Banks } \\
\text { rated " } 2 \text { " }\end{array}$ & $\begin{array}{c}\text { Banks } \\
\text { rated " } 3 \text { " }\end{array}$ & $\begin{array}{l}\text { Banks rated } \\
\text { "4" or " } 5 \text { " }\end{array}$ & $\begin{array}{l}\text { Number of } \\
\text { banks with } \\
\text { CAR }<10 \%\end{array}$ & $\begin{array}{c}\text { Their share } \\
\text { of total } \\
\text { system } \\
\text { assets }\end{array}$ \\
\hline \multicolumn{8}{|c|}{ (Capital-to-Risk Weighted Assets Ratios) } \\
\hline Actual ratio at end-Dec. 2003 & 16.2 & 22.0 & 13.4 & 15.3 & 7.2 & 7 & 28.1 \\
\hline \multicolumn{8}{|l|}{ Scenarios: } \\
\hline $\begin{array}{l}\text { 1. Provisioning increases to } \\
\text { levels required by the RBZ }\end{array}$ & 15.4 & 20.9 & 12.8 & 15.0 & 6.9 & 9 & 29.7 \\
\hline 2. NPLs increase by 50 percent & 14.7 & 19.9 & 11.8 & 14.8 & 6.6 & 11 & 37.0 \\
\hline $\begin{array}{l}\text { 3. } 25 \text { percent of performing } \\
\text { loans become NPLs }\end{array}$ & 8.4 & 13.3 & 2.0 & 11.4 & 3.6 & 19 & 69.8 \\
\hline $\begin{array}{l}\text { 4. } 50 \text { percent of performing } \\
\text { loans become NPLs }\end{array}$ & 0.1 & 4.2 & -12.0 & 7.3 & 0.0 & 21 & 72.3 \\
\hline $\begin{array}{l}\text { 5. Zimbabwean dollar } \\
\text { depreciates by } 80 \text { percent }\end{array}$ & 15.8 & 21.7 & 12.9 & 14.5 & 7.5 & 6 & 25.0 \\
\hline $\begin{array}{l}\text { 6. Increase of short term } \\
\text { interest rates of } 100 \text { percentage } \\
\text { points }\end{array}$ & 14.5 & 16.2 & 19.5 & 12.8 & 5.3 & 13 & 44.7 \\
\hline 7. Combined scenario ${ }^{2 /}$ & 6.2 & 6.5 & 8.2 & 7.9 & 1.9 & 18 & 63.8 \\
\hline
\end{tabular}

Source: Reserve Bank of Zimbabwe

1/ Ratings refer to CAMEL ratings by the RBZ.

2/ Combined scenario includes 25 percent of performing loans becoming NPLs, depreciation of Zimbabwean dollar by

80 percent, and an increase in short-term interest rates by 100 percentage points. 
Table 6. Zimbabwe: Balance of Payments, 2000-2004

(In millions of U.S. dollars, unless otherwise indicated)

\begin{tabular}{|c|c|c|c|c|c|c|}
\hline & \multirow[t]{2}{*}{2000} & \multirow{2}{*}{$\begin{array}{r}2001 \\
\text { Est. }\end{array}$} & \multirow{2}{*}{$\begin{array}{r}2002 \\
\text { Est. }\end{array}$} & \multirow{2}{*}{$\begin{array}{r}2003 \\
\text { Prel. } \\
\text { Est. } \\
\end{array}$} & \multicolumn{2}{|c|}{2004} \\
\hline & & & & & $\begin{array}{l}\text { Baseline } \\
\text { Scenario }\end{array}$ & $\begin{array}{r}\text { Adjustment } \\
\text { Scenario } \\
\end{array}$ \\
\hline Current account (excluding official transfers) & -38 & -497 & -604 & -421 & -445 & -453 \\
\hline Trade balance & 293 & -217 & -525 & -402 & -421 & -408 \\
\hline Exports, f.o.b. & 2,200 & 1,575 & 1,398 & 1,225 & 1,129 & 1,293 \\
\hline Imports, fo.b. & $-1,907$ & $-1,792$ & $-1,923$ & $-1,627$ & $-1,550$ & $-1,701$ \\
\hline Food & -62 & -68 & -337 & -281 & -250 & -250 \\
\hline Nonfood & $-1,846$ & $-1,724$ & $-1,586$ & $-1,346$ & $-1,299$ & $-1,451$ \\
\hline Nonfactor services & -164 & -198 & -203 & -250 & -253 & -275 \\
\hline Receipts & 331 & 243 & 210 & 184 & 169 & 192 \\
\hline Payments & -495 & -441 & -412 & -433 & -422 & -467 \\
\hline Investment income & -358 & -331 & -274 & -278 & -275 & -275 \\
\hline Interest & -142 & -147 & -155 & -171 & -173 & -173 \\
\hline Receipts & 26 & 12 & 10 & 8 & 8 & 8 \\
\hline Payments & -168 & -159 & -165 & -179 & -182 & -182 \\
\hline Other & -217 & -184 & -119 & -107 & $\begin{array}{l}-102 \\
-102\end{array}$ & $\begin{array}{l}-102 \\
-102\end{array}$ \\
\hline Private transfers (incl. transfers to nongovernmental organizations) & 191 & 249 & 398 & 508 & 504 & 504 \\
\hline Capital account (including official transfers) & -227 & -396 & -304 & -256 & 17 & 45 \\
\hline Official transfers & 53 & 40 & 35 & 35 & 35 & 40 \\
\hline Direct investment & 16 & 0 & 23 & 5 & 20 & 30 \\
\hline Portfolio investment & -1 & -68 & -2 & 11 & 20 & 20 \\
\hline Long-term capital & -155 & -282 & -279 & -227 & -240 & -240 \\
\hline Government & -117 & -173 & -185 & -167 & -164 & -164 \\
\hline Receipt & 95 & 42 & 5 & 8 & 0 & 0 \\
\hline Payment & -212 & -214 & -190 & -175 & -164 & -164 \\
\hline Public enterprises & -34 & -74 & -53 & -40 & -58 & -58 \\
\hline Private sector & -4 & -35 & -40 & -20 & -18 & -18 \\
\hline Short-term capital & -140 & -86 & -81 & -79 & 182 & 194 \\
\hline Public sector & 0 & 0 & 0 & 0 & 0 & 0 \\
\hline Private sector & -140 & -86 & -81 & -79 & 182 & 194 \\
\hline Errors and omissions $1 /$ & 130 & 620 & 269 & 103 & 0 & 0 \\
\hline Overall balance & -136 & -273 & -639 & -574 & -427 & -409 \\
\hline Financing & 136 & 273 & 639 & 574 & 427 & 409 \\
\hline Gross official reserves (- increase) & 25 & 2 & 5 & -3 & -6 & -24 \\
\hline Net use of Fund resources & -70 & -85 & -95 & -65 & -36 & -36 \\
\hline Drawings & 0 & 0 & 0 & 0 & 0 & 0 \\
\hline Repayments & -70 & -85 & -95 & -65 & -36 & -36 \\
\hline Other short-term liabilities (net) & -106 & -44 & 13 & 21 & 0 & 0 \\
\hline Change in arrears (decrease, -) & 281 & 399 & 717 & 621 & 452 & 452 \\
\hline Debt relief/rescheduling & 0 & 0 & 0 & 0 & 0 & 0 \\
\hline Valuation adjustment & 0 & 0 & 0 & 0 & 17 & 17 \\
\hline \multicolumn{7}{|l|}{ Memorandum items: } \\
\hline Current account balance (in percent of nominal GDP at world prices) 6/ & -0.4 & -5.9 & -7.9 & -6.0 & -6.5 & -6.6 \\
\hline Gross official reserves $2 / 3 /$ & 22 & 20 & 15 & 18 & 24 & 42 \\
\hline In months of imports of goods and services & 0.1 & 0.1 & 0.1 & 0.1 & 0.2 & 0.2 \\
\hline Reserve liabilities 4 / & 423 & 370 & 381 & 430 & 438 & 438 \\
\hline Net international reserves $4 /$ & -400 & -350 & -366 & -411 & -414 & -396 \\
\hline External debt & 4,014 & 3,845 & 4,370 & 4,843 & 5,204 & 5,204 \\
\hline Of which: arrears & 404 & 803 & 1,520 & 2,141 & 2,593 & 2,593 \\
\hline External debt service due $5 /$ & 579 & 572 & 564 & 499 & 458 & 458 \\
\hline Debt service ratio (as a percent of exports of goods and non-factor services) & 22.9 & 31.4 & 35.1 & 35.4 & 35.3 & 30.8 \\
\hline Nominal GDP at the official exchange rate (US\$ millions) & 7,399 & 10,256 & 21,897 & 8,753 & 5,762 & 5,762 \\
\hline Nominal GDP at world prices (US\$ millions) 6/ & 8,542 & 8,485 & 7,662 & 7,081 & 6,822 & 6,887 \\
\hline
\end{tabular}

Sources: Zimbabwean authorities; and staff estimates and projections.

$1 /$ Include flows associated with underinvoicing of exports and arrears on short-term private debt.

2/ End of period.

3/ Gold valued at market prices.

4/ Reported by the Reserve Bank of Zimbabwe.

5/ Scheduled medium- and long-term amortization plus all interest payments.

6/ Nominal U.S. dollar GDP adjusted for real growth and international inflation (1996 base year). 
Table 7. Medium Term Outlook, 2003-2009 1/

\begin{tabular}{|c|c|c|c|c|c|c|c|}
\hline & $\begin{array}{l}2003 \\
\text { Proj. }\end{array}$ & $\begin{array}{l}2004 \\
\text { Proj. }\end{array}$ & $\begin{array}{l}005 \\
\text { Proj. }\end{array}$ & $\begin{array}{l}006 \\
\text { Proj. }\end{array}$ & $\begin{array}{l}2007 \\
\text { Proj. }\end{array}$ & $\begin{array}{l}2008 \\
\text { Proj. }\end{array}$ & $\begin{array}{l}2009 \\
\text { Proj. }\end{array}$ \\
\hline \multicolumn{8}{|l|}{ GDP } \\
\hline Nominal GDP (Z\$ billions) & 5,810 & 24,940 & 139,169 & 402,320 & 636,871 & 757,923 & 851,028 \\
\hline Nominal GDP at the official excange rate (US\$ billions) & 8.8 & 5.8 & 3.2 & 3.0 & 3.3 & 3.6 & 4.0 \\
\hline Nominal GDP at world prices (US\$ billions) & 7.1 & 6.8 & 7.1 & 7.5 & 8.0 & 8.6 & 9.1 \\
\hline Real GDP (market prices; pct change) & -9.3 & -5.2 & 1.8 & 4.6 & 4.4 & 4.2 & 4.2 \\
\hline Real per capita GDP (percentage change) & -9.1 & -4.9 & 1.8 & 4.6 & 4.4 & 4.2 & 4.2 \\
\hline \multicolumn{8}{|l|}{ Savings and investment (percent of GDP) } \\
\hline Gross national savings (excluding grants) & -3.0 & -4.6 & -9.7 & -7.0 & -4.0 & -1.8 & 0.0 \\
\hline Gross investment & 1.9 & 3.1 & 3.1 & 4.1 & 5.6 & 7.1 & 8.1 \\
\hline \multicolumn{8}{|l|}{ Prices and interest rates (percent) } \\
\hline CPI inflation (annual average) & 431.7 & 352.6 & 448.0 & 176.3 & 51.7 & 14.2 & 7.8 \\
\hline CPI inflation (end of period) & 598.7 & 256.4 & 435.9 & 100.7 & 27.6 & 9.8 & 6.0 \\
\hline 91-day treasury bills (annualized yield; end of period) & 60.7 & 200.0 & 425.0 & 120.0 & 30.0 & 15.0 & 8.5 \\
\hline \multicolumn{8}{|l|}{ Central government budget (percent of GDP; calendar-year basis) } \\
\hline Revenue & 23.7 & 25.0 & 26.6 & 26.5 & 26.3 & 26.1 & 25.9 \\
\hline Expenditure and net lending & 24.0 & 34.7 & 37.9 & 34.2 & 33.0 & 32.3 & 31.5 \\
\hline Of which: interest on central government debt & 1.2 & 8.3 & 13.0 & 8.6 & 5.4 & 4.0 & 3.4 \\
\hline Overall balance, excluding grants and arrears & -0.3 & -9.7 & -11.3 & -7.7 & -6.7 & -6.2 & -5.5 \\
\hline Primary balance, excluding grants & 0.8 & -1.4 & 1.7 & 0.9 & -1.3 & -2.2 & -2.2 \\
\hline Overall balance, including grants and interest arrears & -0.2 & -7.3 & -7.7 & -6.8 & -5.1 & -4.4 & -3.6 \\
\hline Domestic financing (including privatization) & 0.2 & 7.3 & 7.7 & 2.9 & 0.3 & 0.0 & 0.0 \\
\hline External financing (including principal arrears) & 0.0 & 0.0 & 0.0 & 4.0 & 4.8 & 4.4 & 3.6 \\
\hline Total public debt (percent of GDP; end of period) & 63.6 & 99.5 & 165.5 & 176.3 & 164.5 & 157.0 & 151.0 \\
\hline Domestic debt & 10.2 & 15.4 & 11.4 & 9.4 & 9.3 & 11.4 & 14.0 \\
\hline External debt (public and publicly guaranteed) & 53.4 & 84.2 & 154.0 & 166.9 & 155.2 & 145.6 & 137.0 \\
\hline \multicolumn{8}{|l|}{ Money and credit (percent change; end of period) } \\
\hline Broad money (M3) & 413.5 & 252.8 & 452.8 & 96.6 & 26.0 & 9.5 & 6.4 \\
\hline Domestic credit & 397.6 & 240.1 & 360.9 & 97.5 & 26.9 & 10.8 & 7.3 \\
\hline Credit to the private sector & 522.1 & 195.7 & 375.7 & 105.5 & 31.6 & 13.7 & 9.1 \\
\hline \multicolumn{8}{|l|}{ External trade (percent change) } \\
\hline Export volume & -17.3 & -11.3 & 0.5 & 12.1 & 6.4 & 6.4 & 6.0 \\
\hline Import volume & -21.5 & -8.5 & -4.9 & 2.7 & 4.4 & 4.8 & 5.0 \\
\hline Terms of trade & -1.7 & -0.3 & 2.3 & -2.0 & -2.0 & -0.7 & -0.9 \\
\hline \multicolumn{8}{|l|}{ Balance of payments (US\$ billions, unless otherwise indicated) } \\
\hline Exports & 1.23 & 1.13 & 1.16 & 1.28 & 1.34 & 1.43 & 1.52 \\
\hline Imports & -1.63 & -1.55 & -1.47 & -1.52 & -1.60 & -1.69 & -1.79 \\
\hline Current account balance (excluding official transfers) & -0.42 & -0.44 & -0.41 & -0.34 & -0.32 & -0.32 & -0.32 \\
\hline (in percent of GDP) & -4.8 & -7.7 & -12.8 & -11.1 & -9.6 & -8.9 & -8.1 \\
\hline Overall balance & -0.57 & -0.43 & -0.31 & 0.69 & 0.07 & 0.09 & 0.12 \\
\hline \multicolumn{8}{|l|}{ Official reserves (gold valued at market price) } \\
\hline Usable reserves (US\$ millions, end of period) & 18.3 & 24.0 & 23.6 & 136.2 & 279.2 & 434.7 & 616.0 \\
\hline (months of imports of goods and services) & 0.1 & 0.2 & 0.1 & 0.8 & 1.6 & 2.4 & 3.3 \\
\hline (percent of short-term debt) & 3.7 & 3.7 & 3.0 & 14.7 & 26.2 & 36.3 & 51.8 \\
\hline (percent of reserve money) & 2.1 & 5.1 & 15.4 & 84.1 & 163.0 & 235.7 & 314.8 \\
\hline \multicolumn{8}{|l|}{ External debt and arrears (including private debt) } \\
\hline Total external debt (percent of GDP at world prices; end of period) 2/ & 68.4 & 76.3 & 77.1 & 75.5 & 74.1 & 72.6 & 71.2 \\
\hline Debt service (percent of exports of goods and services) & 35.4 & 35.3 & 30.9 & 26.0 & 22.4 & 20.5 & 18.4 \\
\hline Total external arrears (percent of GDP at world prices; end of period) 2/ & 30.2 & 38.0 & 41.1 & 2.4 & 1.5 & 0.7 & 0.0 \\
\hline
\end{tabular}

Sources: Zimbabwean authorities; and staff estimates and projections.

1/ Foreign currency units are converted into Zimbabwean dollars at the official exchange rate.

2/ GDP at world prices using real GDP growth and trading partner countries' inflation (base year is 1996). 


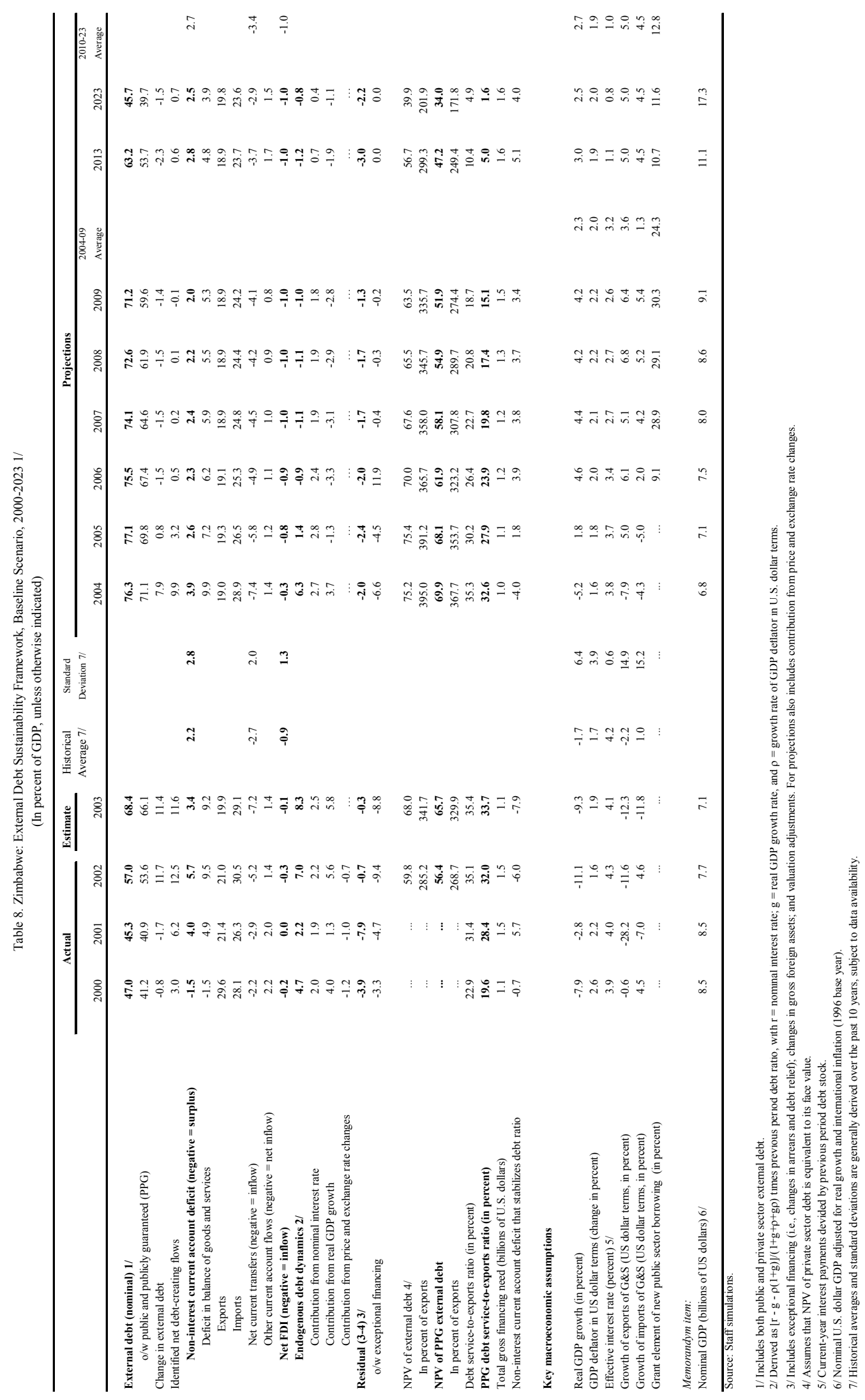


Table 9. Zimbabwe: Sensitivity Analyses for Key Indicators of Public and Publicly Guaranteed External Debt, 2003-23 (In percent)

\begin{tabular}{|c|c|c|c|c|c|c|c|c|}
\hline & & & & Projec & & & & \\
\hline & 2004 & 2005 & 2006 & 2007 & 2008 & 2009 & 2013 & 2023 \\
\hline NP & & & & & & & & \\
\hline Baseline & 70 & 68 & 62 & 58 & 55 & 52 & 47 & 34 \\
\hline A. Alternative Scenarios & & & & & & & & \\
\hline A1. Key variables at their historical averages in 2004-23 1/ & 65 & 65 & 62 & 61 & 61 & 61 & 63 & 64 \\
\hline A2. New public sector loans on less favorable terms in 2004-23 2/ & 70 & 68 & 68 & 65 & 62 & 60 & 60 & 58 \\
\hline B. Bound Tests & & & & & & & & \\
\hline B1. Real GDP growth at historical average minus one standard deviation in 2004-05 & 72 & 77 & 70 & 66 & 62 & 59 & 54 & 39 \\
\hline B2. Export value growth at historical average minus one standard deviation in 2004-05 3/ & 71 & 74 & 68 & 64 & 61 & 58 & 51 & 35 \\
\hline B3. US dollar GDP deflator at historical average minus one standard deviation in 2004-05 & 72 & 73 & 66 & 62 & 59 & 56 & 51 & 36 \\
\hline B4. Net non-debt creating flows at historical average minus one standard deviation in 2004-05 4/ & 77 & 81 & 74 & 70 & 67 & 63 & 56 & 36 \\
\hline B5. Combination of B1-B4 using one-half standard deviation shocks & 76 & 87 & 80 & 76 & 72 & 69 & 60 & 39 \\
\hline B6. One-time 30 percent nominal depreciation relative to the baseline in 20045 / & 99 & 97 & 88 & 83 & 78 & 74 & 67 & 48 \\
\hline
\end{tabular}

NPV of debt-to-exports ratio

Baseline

A. Alternative Scenarios

A1. Key variables at their historical averages in 2004-23 1/

A2. New public sector loans on less favorable terms in 2004-23 2

B. Bound Tests

B1. Real GDP growth at historical average minus one standard deviation in 2004-05 B2. Export value growth at historical average minus one standard deviation in 2004-05 3/ B3. US dollar GDP deflator at historical average minus one standard deviation in 2004-05 B4. Net non-debt creating flows at historical average minus one standard deviation in 2004-05 4 B5. Combination of B1-B4 using one-half standard deviation shocks

B6. One-time 30 percent nominal depreciation relative to the baseline in 2004 5/

Debt service ratio

Baseline

A. Alternative Scenarios

A1. Key variables at their historical averages in 2004-23 $1 /$

A2. New public sector loans on less favorable terms in 2004-23 2/

\section{B. Bound Tests}

B1. Real GDP growth at historical average minus one standard deviation in 2004-05 B2. Export value growth at historical average minus one standard deviation in 2004-05 3/ B3. US dollar GDP deflator at historical average minus one standard deviation in 2004-05

B4. Net non-debt creating flows at historical average minus one standard deviation in 2004-05 4 B5. Combination of B1-B4 using one-half standard deviation shocks

B6. One-time 30 percent nominal depreciation relative to the baseline in 2004 5/

Memorandum item:

Grant element assumed on residual financing (i.e., financing required above baseline) $6 /$

Source: Staff projections and simulations.

1/ Variables include real GDP growth, growth of GDP deflator (in U.S. dollar terms), non-interest current account in percent of GDP, and non-debt creating flows.

2/ Assumes that the interest rate on new borrowing is by 2 percentage points higher than in the baseline., while grace and maturity periods are the same as in the baseline.

3/ Exports values are assumed to remain permanently at the lower level, but the current account as a share of GDP is assumed to return to its baseline level after the shock (implicitly assuming an offsetting adjustment in import levels).

4/ Includes official and private transfers and FDI.

5/ Depreciation is defined as percentage decline in dollar/local currency rate, such that it never exceeds 100 percent.

6/ Applies to all stress scenarios except for A2 (less favorable financing) in which the terms on all new financing are as specified in footnote 2. 
Figure 4. Zimbabwe: Selected Economic and Financial Indicators
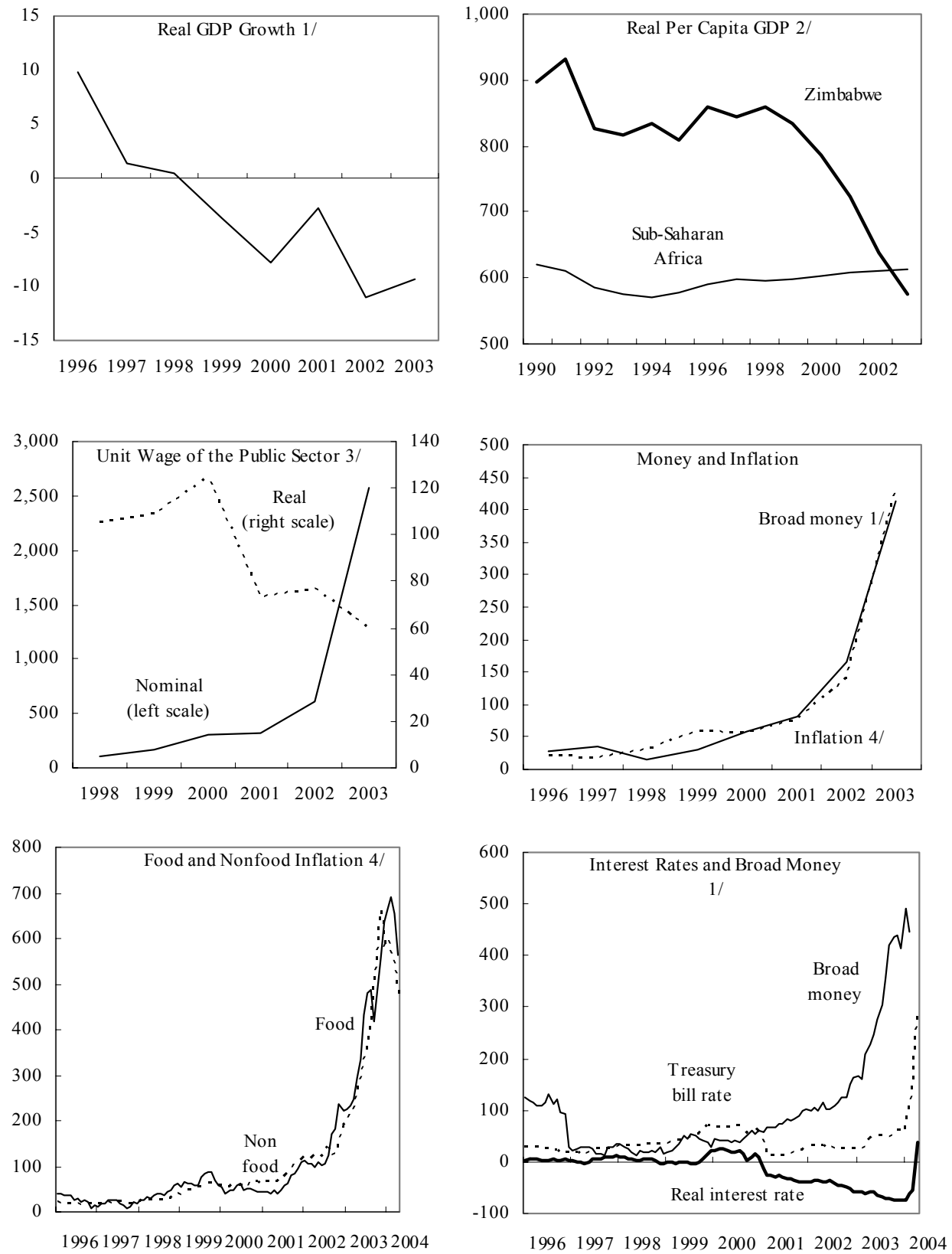

Sources: Zimbabwean authorities; and staff estimates for 2003.

1/ In percent.

2/ Based on real GDP, population growth, and the average dollar exchange rate in 1990.

3/ In thousands of Zimbabwean dollars per employee.

4/ Percentage change in consumer prices (yearly average). 
Figure 4. Zimbabwe: Selected Economic and Financial Indicators (concluded)
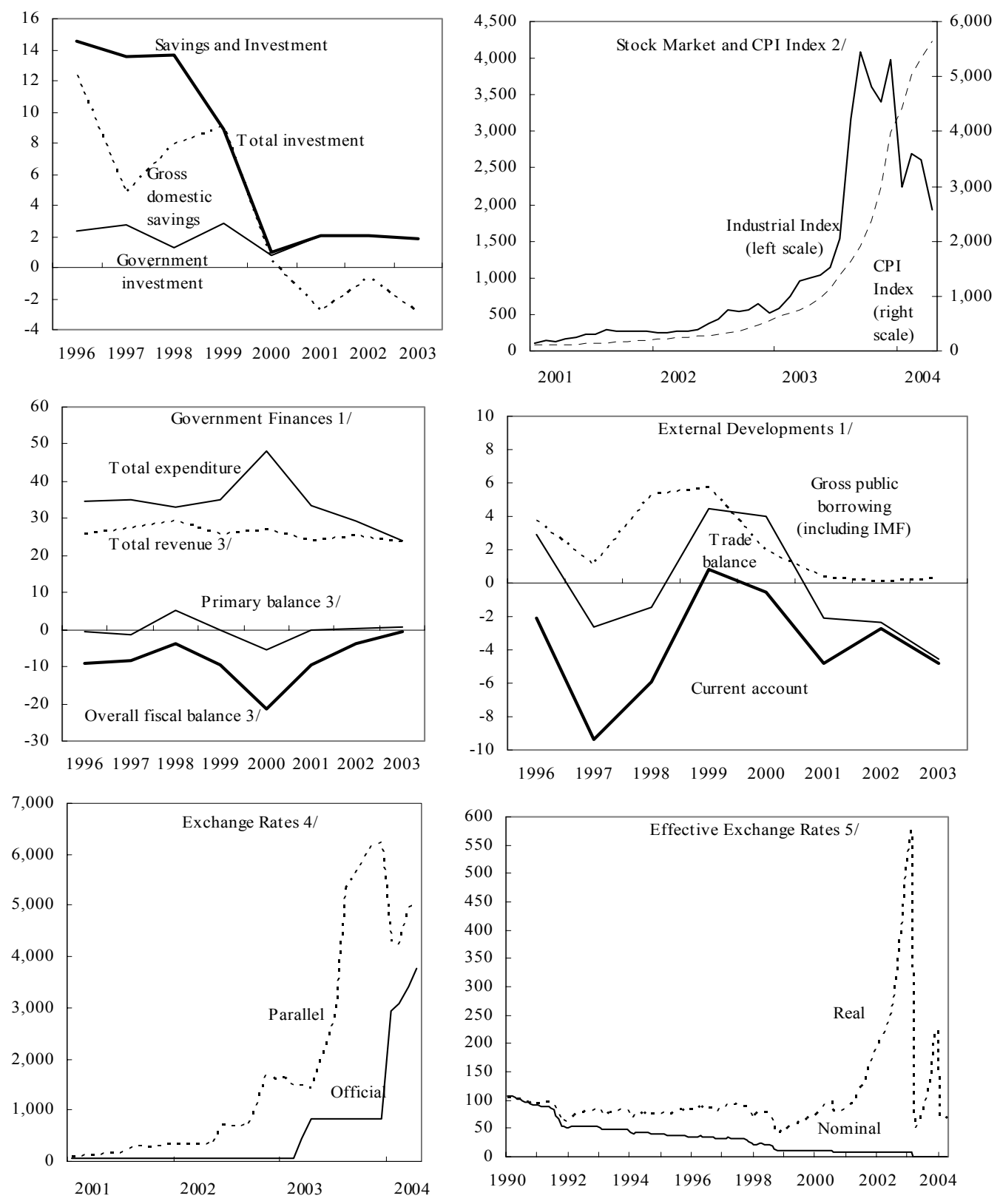

Sources: Zimbabwean authorities; Zimbabwe market sources; and staff estimates for 2003.

1/ In percent of GDP.

$2 /$ Index $2000=100$

3/ Excluding grants.

4/ In Zimbabwe dollars per US\$. From January 2004, the official rate reflects a blend between the surrender rate of $Z \$ 824$ per US\$ ( 25 percent) and the average tender rate ( 75 percent).

$5 /$ Index 1990=100. Based on the offical exchange rate. 


\section{Zimbabwe: Social Issues}

\section{Social and Demographic Indicators}

Table 1: Selected Social and Demographic Indicators

Population (millions)

Area (sq. km.)

Density (per sq. km.)

Labor force (millions)

Urban Population (percent of total)

HIV incidence (percent of adult population, age 15-49)

$\begin{array}{rr}11.6 & (2002) \\ 386,850 & (2002) \\ 30.1 & (2002) \\ 5.9 & (2001) \\ 36.0 & (2001) \\ 24.6 & (2003)\end{array}$

\begin{tabular}{crrrr}
\multicolumn{2}{c}{$\begin{array}{c}\text { Latest Best } \\
\text { Performance }\end{array}$} & & \multicolumn{2}{c}{ Latest Known } \\
\cline { 1 - 1 } \cline { 4 - 5 } Date & Data & & Date & Data \\
& & & \\
1983 & 3.9 & & 2002 & -0.3 \\
1990 & 56.2 & & 2002 & 39.0 \\
1990 & 53.0 & & 2002 & 76.0 \\
1967 & 7.5 & & 2002 & 3.7 \\
& & & \\
1995 & 74.0 & & 2002 & 80.0 \\
1995 & 57.0 & & 2002 & 69.0 \\
1981 & $1,100.0$ & 2001 & 480.0
\end{tabular}

Health

Health expenditure per capita (current US\$)

1997

66.0

$2001 \quad 45.0$

Education

Expenditure per student, primary (percent of GDP per capita)
1999

29.5

2001

16.2

Zimbabwean authorities. 
Zimbabwe: Selected Social and Demographic Indicators (concluded)

Human Development Index, 1975-2001

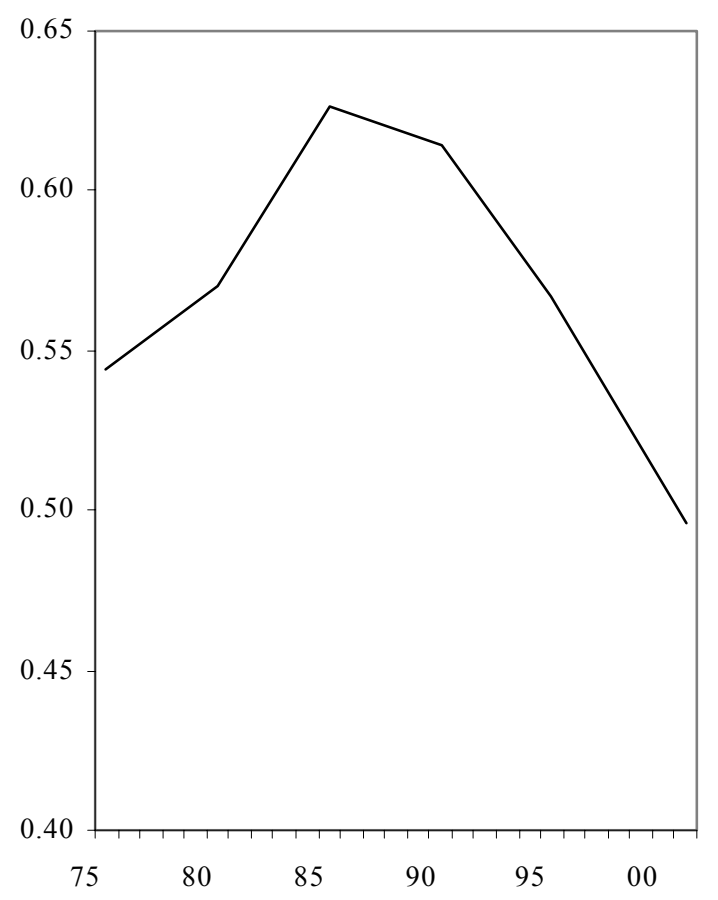

Expenditure per student (percent of GDP per capita), 1970-2002

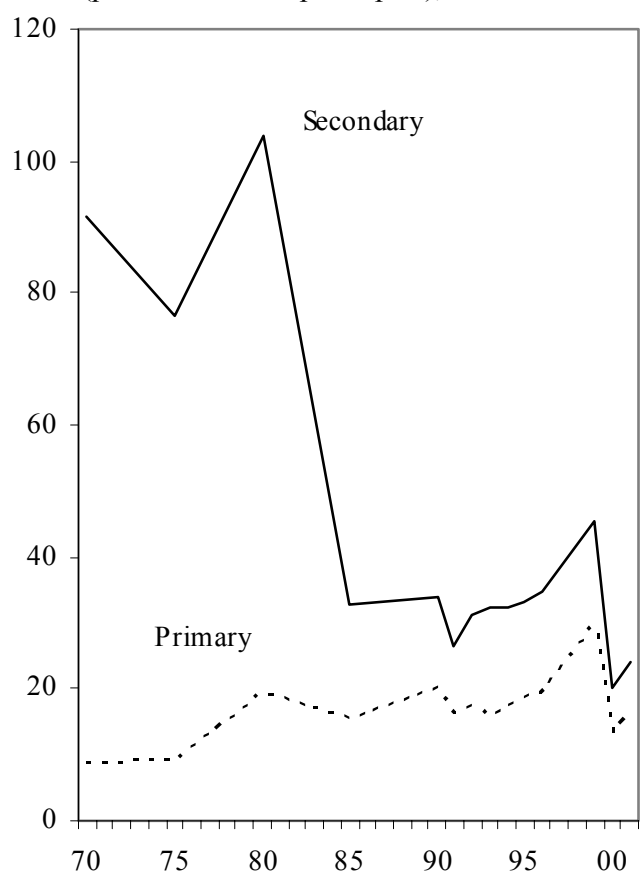

Life expectancy (years) and mortality rates (per 1,000 live births), 1960-2002

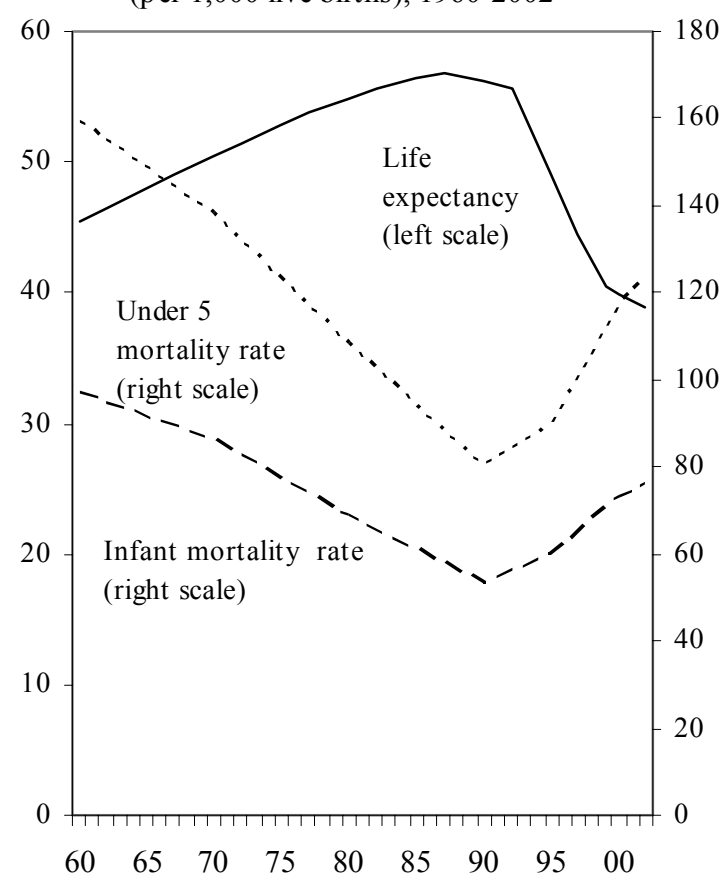

Immunization

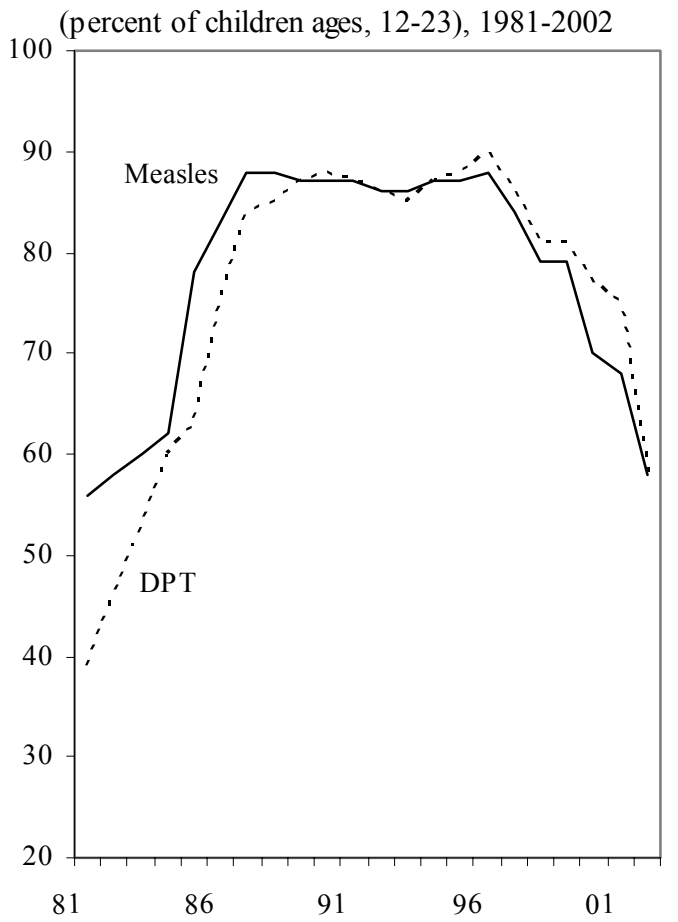

Sources: World Bank, World Development Indicators April 2003; UNDP, Human

Development Report 2003. 


\section{HIV/AIDS Pandemic}

Incidence. Zimbabwe has one of the highest HIV/AIDS prevalence rates in the world, currently estimated at 24.6 percent of the adult population (aged 15 to 49 years) and reaching 35 percent in some areas. The 2003 HIV/AIDS report, prepared jointly by the Ministry of Health and Child Welfare (MOHCW) and the United Nations Program on HIV/AIDS (UNAIDS), estimates that some 1.8 million Zimbabweans were living with HIV, over half of them women. Zimbabwe had around 800,000 AIDS orphans in 2003. Some 206,000 new HIV infections and 174,000 new AIDS cases were reported in 2003. The total number of AIDS-related deaths during 2003 was estimated to reach 171,300 , close to 500 each day. Life expectancy has declined from around 60 years in 1997 to below 40 years since 2001 .

Impact on the health sector. The overall macroeconomic decline and the emigration of health professionals have severely constrained health sector operations. In addition, the HIV/AIDS pandemic has exerted an unbearable pressure on hospitals and other health centers. About 80 percent of the hospital beds are occupied for AIDS-related illnesses. The MOHCW estimates the annual cost of anti-retro viral (ARV) treatment, excluding equipment and other overheads, at US\$260-300. The shortage of foreign currency, however, is constraining the availability of ARV drugs. Currently 5,000 AIDS patients receive ARV treatment, while estimates of people in need of such treatment vary from 260,000 to 500,000 . Under the WHO's 3 by 5 program, the plan is to provide ARV treatment to 200,000 patients within the next 2 years. Given the current state of the health sector and the financing constraints, it is not clear how the target can be achieved.

HIV/AIDS and the food situation. Chronic food shortages and inadequate nutritional standards continue to have an adverse impact on the health of AIDS patients and have created a vicious cycle of malnourishment and disease. Land reform has displaced more than a million commercial farm workers and consequently worsened food security and the traditional home-based health care services provided on farms. As the pandemic has significantly affected the agriculture sector, food insecurity, HIV/AIDS, and low labor productivity are reinforcing each other.

Government strategy to combat HIV/AIDS. The government has adopted a multi-sector strategy headed by the National Aids Council (NAC), which coordinates all government treatment, prevention, and impact mitigation efforts. Each ministry has assigned focal persons for AIDS to ensure effective communication with the NAC. At present, the government runs 21 voluntary counseling and testing (VCT) centers. An ARV program started with two centers in Harare and Bulawayo. The AIDS levy, a 3 percent surcharge on taxable income, was introduced in 2000 and serves as the main source of funding for the NAC; collections amounted to Z\$15 billion in 2003. The NAC allocates its fund through 87 District AIDS Councils (DAC) based on their delivery capacities and previous track records. The government is also expecting US\$14 million from the UN Global Fund for AIDS, Tuberculosis, and Malaria, and has applied for another tranche of US\$80 million. The Global Fund allocation will be used to strengthen education, home-based care, and ARV treatment. However, transparent guidelines need to be put in place to ensure that the criteria for receiving the ARV treatment are not driven by political considerations. The effectiveness of the government's strategy to combat HIV/AIDS is constrained by a lack of health professionals and limited. 
III. Millenium Development Goals

Table 2: Millennium Development Goals

$1990 \quad 1995 \quad 2001 \quad 2002 \quad 2003 \frac{2015}{\text { Target }}$

Goal 1. Eradicate extreme poverty and hunger

Target 1: Halve, between 1990 and 2015, the proportion of people whose income

is less than one dollar a day.

1. Population below US\$1 a day (percent)

2. Poverty gap ratio at US\$1 a day (percent)

3. Share of income or consumption held by poorest 20 percent (percent)

36.0

9.6

$\cdots$

Target 2: Halve, between 1990 and 2015, the proportion of people suffering hunger

4. Prevalence of child malnutrition (percent of children under 5)

5. Population below minimum level of dietary energy consumption (percent)

Goal 2. Achieve universal primary education

Target 3: Ensure that, by 2015, children will be able to complete a full course of primary schooling

6. Net primary enrollment ratio (percent of relevant age group)

7. Percentage of cohort reaching grade 5

8. Youth literacy rate (percent ages 15-24)

$\underline{\text { Goal 3. Promote gender equality and empower women }}$

Target 4: Eliminate gender disparity in primary and secondary education preferably by 2005 and to all levels of education by 2015

9. Ratio of girls to boys in primary and secondary education (percent)

10. Ratio of young literate females to males (percent ages 15-24)

11. Share of women employed in the nonagricultural sector (percent)

12. Proportion of seats held by women in the national parliament (percent)

$\begin{array}{rrrrrr}95.3 & 93.7 & 95.0 & \ldots & \ldots & 100.0 \\ 94.6 & 96.1 & 97.1 & 97.3 & \ldots & \ldots \\ 15.4 & 17.2 & 20.2 & \ldots & \ldots & \ldots \\ \ldots & 15.0 & \ldots & \ldots & \ldots & \ldots\end{array}$

\section{Goal 4. Reduce child mortality}

Target 5: Reduce by two-thirds, between 1990 and 2015, the under-five mortality rate

13. Under-five mortality rate (per 1,000 )

14. Infant mortality rate (per 1,000 live births)

15. Immunization against measles (percent of children under 12-months)

80.0

53.0

87.0
90.0

60.0

87.0
117.0

73.0

68.0

\section{Goal 5. Improve maternal health}

Target 6: Reduce by three-quarters, between 1990 and 2015, the maternal mortality ratio.

16. Maternal mortality ratio (modeled estimate, per 100,000 live births)

17. Proportion of births attended by skilled health personnel

Goal 6. Combat HIV/AIDS, malaria and other diseases

Target 7: Halt by 2015, and begin to reverse, the spread of HIV/AIDS

18. HIV prevalence (percent ages 15-24)

19. Contraceptive prevalence rate (percent of women ages 15-49)

20. Number of children orphaned by HIV/AIDS

\begin{tabular}{rrrrrr}
$\ldots$ & $\ldots$ & $\ldots$ & $\ldots$ & 24.6 & $\ldots$ \\
43.1 & 48.1 & 53.5 & $\ldots$ & $\ldots$ & $\ldots$ \\
$\ldots$ & $\ldots$ & 780,000 & $\ldots$ & $\ldots$ & $\ldots$ \\
& & & & & \\
& & & & & \\
& & & & & \\
$\ldots$ & $\ldots$ & $\ldots$ & $\ldots$ & $\ldots$ & $\ldots$ \\
$\ldots$ & $\ldots$ & $\ldots$ & $\ldots$ & $\ldots$ & $\ldots$ \\
$\ldots$ & $\ldots$ & 628 & 683 & $\ldots$ & $\ldots$ \\
$\ldots$ & $\ldots$ & 47.0 & 45.9 & $\ldots$ & $\ldots$ \\
\hline
\end{tabular}


APPENDIX I

Table 2: Millennium Development Goals (concluded)

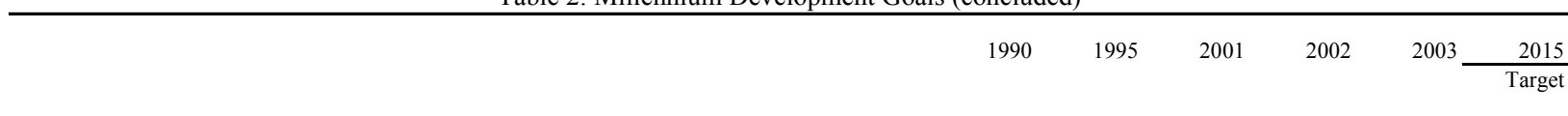

\section{Goal 7. Ensure environmental sustainability}

Target 9: Integrate the principles of sustainable development into policies and programs. Reverse the loss of environmental resources.

25. Forest area (percent of total land area)

26. Nationally protected areas (percent of total land area)

27. GDP per unit of energy use (PPP \$ per kg oil equivalent)

28. $\mathrm{CO} 2$ emissions (metric tons per capita)

29. Proportion of population using solid fuels

Target 10: Halve,between 1990 and 2015, the proportion of people without access to safe drinking wate

30. Access to improved water source (percent of population)

Target 11: Achieve by 2020 significant improvement for at least 100 million slum dwellers

31. Access to improved sanitation (percent of population)

32. Access to secure tenure (percent of population)

\section{Goal 8. Develop a Global Partnership for Development 1/}

Target 16: Develop and implement strategies for productive work for youth.

45. Unemployment rate of population ages 15-24 (total)

Female

Male

Target 17: Provide access to affordable essential drugs

46. Proportion of population with access to affordable essential drugs

Target 18: Make available new technologies, especially information and communications

47. Fixed line and mobile telephones (per 1,000 people)

48. Personal computers (per 1,000 people)

$\begin{array}{rrrr}12.6 & 14.2 & 50.6 & 55.1 \\ 0.2 & 3.1 & 17.4 & 51.6\end{array}$

Source: World Bank., World Development Indicators, April 2004; and World Health Organization.

1/ Targets 12-15 and indicators 33-44 are excluded because they can not be measured on a country specific basis. These are related to official development assistance, market access, and the HIPC initiative. 


\section{Zimbabwe: Relations with the Fund ${ }^{13}$}

(As of April 30, 2004)

I. Membership Status: Joined: 09/29/1980; Article VIII obligations accepted 2/5/1995.

II. General Resources Account:

Quota

Fund holdings of currency

Reserve position in Fund

III. SDR Department:

Net cumulative allocation

Holdings

IV. Outstanding Purchases and Loans:

Stand-By Arrangements

Extended Arrangements

Poverty Reduction Growth Facility

(PRGF) Arrangements $\underline{\text { SDR Million }}$

353.40

470.58

0.33

$\underline{\text { SDR Million }}$

10.20

0.01

$\underline{\text { SDR Million }}$

63.94

53.56

81.38
\% Quota

100.0

133.2

0.1

$\%$ Allocation

100.0

0.1

\% Quota

18.1

15.2

23.0

V. Financial Arrangements:

Approval Expiration

Type

Stand-By Arrangement

Stand-By Arrangement

Extended Fund Facility (EFF)
Amount Amount Drawn

Approved

(SDR Million) (SDR Million)

141.36

24.74

130.65

39.20

114.60

86.90

VI. Projected Obligations to Fund (SDR million; based on existing use of resources and present holdings of SDRs):

\begin{tabular}{|c|c|c|c|c|c|c|}
\hline & Overdue & & & Forthco & & \\
\hline & $04 / 30 / 2004$ & 2004 & 2005 & 2006 & 2007 & 2008 \\
\hline Principal & 182.8 & 11.1 & 4.9 & 0.0 & 0.0 & 0.0 \\
\hline Charges/interest & $\underline{13.9}$ & 2.4 & 2.9 & 2.9 & 2.9 & 2.9 \\
\hline Total & 196.7 & 13.5 & 7.8 & 2.9 & 2.9 & 2.9 \\
\hline
\end{tabular}

VII. Application of Remedial Measures under the Arrears Strategy

${ }^{13}$ For further information, please contact Mr. Dauphin (IMF/AFR, (202) 62397 05), or Ms. Treichel, (IMF/FIN, (202) 62368 89). 
Zimbabwe has been in continuous arrears to the Fund since February 2001. On September 24, 2001 the Executive Board declared the country ineligible to use the general resources of the Fund and removed it from the list of PRGF-eligible countries. On June 13, 2002, the Board issued a declaration of non-cooperation with respect to Zimbabwe and suspended all technical assistance to the country. On June 6, 2003, the Board suspended Zimbabwe's voting and related rights in the Fund. On December 3, 2003, the Board noted that it was intended to initiate the procedure on compulsory withdrawal with respect to Zimbabwe. Subsequently, the Managing Director issued a complaint regarding Zimbabwe's persistent failure to fulfill its obligations on February 6, 2004, and the Board decided to place the complaint on its agenda for substantive consideration on July 7, 2004.

\section{Exchange Rate Arrangement:}

The authorities maintained a fixed exchange rate regime and surrender requirements during 2003 in the face of rising domestic inflation and declining exports. As the currency became increasingly overvalued, a vibrant parallel market developed that was illegal but tolerated, and inflows into the official market virtually dried up. Ad-hoc measures were implemented during the year to compensate and to provide incentives to exporters.

- The official exchange rate for government transactions remained at Z\$55/US\$, but that for non-state entities was devalued to Z\$824/US\$ in March 2003.

- $\quad$ Exporters were required to surrender 50 percent of proceeds (net of debt service on foreign loans) at the exchange rate of Z\$824/US\$; they were allowed to retain the remainder in foreign currency accounts (FCAs) for a maximum period of 60 days. From July 2003, exporters were exempted from surrender requirements on incremental exports.

- Tobacco farmers were paid at the official exchange rate of Z\$824/US\$. Initially, they were not allowed any retention but later in the year a retention amount of 20 percent was introduced through the Tobacco Growers Trust.

- $\quad$ The 50 percent that exporters were allowed to retain had to be deposited with the RBZ and its utilization was limited to a priority list of imports and subject to RBZ approval.

- $\quad$ As the overvaluation in the official market grew, so did the parallel market. Towards the end of 2003, the currency was trading at Z\$6,000/US\$ in this market.

In recognition of the onerous nature of the surrender requirements and to increase foreign exchange inflows in official channels, the authorities announced a new exchange regime in December 2003 and made further minor changes in April 2004. The new exchange regime allows the exchange rate to be determined through a heavily managed tender system ("auction"). Surrender requirements were eased, but the parallel market was sharply curtailed and driven underground. Key features of the new regime are:

- $\quad$ A tender system operated by the RBZ to sell foreign exchange twice a week. Authorized dealers submit detailed bids on behalf of customers, including such 
transaction information as intended use of foreign exchange and approval number by the RBZ. An RBZ committee scans the bids and eliminates those that are for nonpriority purposes. The rest of the bids are admitted to the tender system and allocated foreign exchange on the basis of price. The tender system is price discriminatory in nature in that successful bidders actually pay the price they bid for the foreign exchange and not a uniform price.

- $\quad$ A floor exchange rate of Z\$5,200/US\$ is guaranteed to exporters and transfers from the diaspora since late-April 2004.

- $\quad$ A carrot and stick retention scheme has been introduced. This scheme reduced surrender requirements to 25 percent of gross export proceeds at the rate of Z\$824/US\$ and provided incentives for export prepayments. Exporters also surrender a percentage of their gross proceeds to supply the tender; the percentage varies largely according to the time lag between export and receipt of payment.

- $\quad$ The RBZ uses foreign currency surrendered at Z\$824/US\$ for government and NOCZIM imports. Other parastatals source their foreign exchange needs from the tender system (or payments in foreign exchange in the case of ZESA).

- $\quad$ Retention period in FCAs is reduced to 30 days from 60 days. The priority list for the use of FCA deposits has been abolished and procedures for obtaining RBZ approval for imports have been simplified.

- A whistleblower fund has been instituted to punish those that engage in parallel market dealing. Several arrests have been made.

After an initial appreciation of the tender rate from Z\$4,197/US\$ in mid-January to Z\$3,520/US\$ in early February, the tender rate depreciated to Z\$5,272/US\$ at end-April. However, there has been a substantial appreciation of the average exchange rate since late last year because of the clamp down on the parallel market. The authorities have welcomed the dampening impact this has had on inflation. They are managing the tender system in a way that does not allow the tender rate to fully reflect market forces.

As a result of this system, Zimbabwe currently has restrictions on the making of transfers and payments for current international transactions, and multiple currency practices, inconsistent, respectively, with Article VIII Sections 2(a) and 3 of the Fund's Articles of Agreement. Zimbabwe maintains multiple currency practices (MCP) arising from the lack of a mechanism to prevent a divergence of more than 2 percent between (i) the exchange rates in the official and parallel markets, (ii) the exchange rates applicable for private sector imports and government imports, (iii) the exchange rates paid by successful bidders in the same tender, and (iv) the exchange rate used for surrender of export receipts (weighted average rate from each auction) and the other rates in the exchange market. Zimbabwe also maintains exchange restrictions arising from (i) limitations on the availability of foreign exchange, in the form of priority lists that limit the provision of foreign exchange for certain specified transactions which are subject to the approval of the RBZ, and (ii) the existence of private 
sector external payment arrears inconsistent with Article VIII Section 2(a). These restrictions and MCPs have not been approved by the Board.

Staff was informed of the existence of bilateral payments arrangements with Fund members, which may raise issues of compliance by Zimbabwe with Article VIII obligations. Staff was unable to obtain relevant materials, but is continuing to seek information from the authorities in order to reach a conclusion on these issues. Exchange restrictions arising from certain outstanding contracts under a discontinued RBZ scheme for foreign exchange cover have been discontinued.

\section{Article IV Consultation:}

Zimbabwe is on the standard 12-month consultation cycle. The last Article IV consultation was concluded on June 6, 2003 (EBM/03/53).

\section{Technical Assistance:}

The Executive Board suspended Fund technical assistance to Zimbabwe in June 2002. Past Fund technical assistance to Zimbabwe is summarized in the attached table. A long-term advisor sponsored by MFD provided assistance in the area of banking supervision between August 1996 and October 1999. Another MFD expert on monetary operations provided advice to the RBZ and trained staff in the implementation of open market operations and the use of repurchase agreements during October 1998 - October 2000. A third MFD expert on the payments system, who also advised the RBZ on the array of monetary instruments to be used to monitor and manage liquidity in the financial sector, completed a one-year assignment in October 1999.

\section{Resident Representative:}

A resident representative office was opened in July 1993. Mr. G. G. Johnson's term as Senior Resident Representative expired at end-September 2003. The office has remained open with local staff, and there are plans to close the office at end-September 2004. 
Zimbabwe: Technical Assistance from the Fund (Since the Inception of the PRGF/EFF Arrangements in September 1992)

\begin{tabular}{|c|c|c|c|}
\hline Date & Department & Purpose & Result \\
\hline November 1992 & STA & Revise monetary statistics. & Revision initiated. \\
\hline April 1993 & MFD & $\begin{array}{l}\text { Liberalize foreign exchange } \\
\text { system. }\end{array}$ & $\begin{array}{l}\text { Comprehensive } \\
\text { reforms launched; } \\
\text { completed in July } \\
1994 .\end{array}$ \\
\hline Spring 1994 & LEG & $\begin{array}{l}\text { Revise the Reserve Bank Act } \\
\text { and the Banking Act. }\end{array}$ & Completed. \\
\hline Spring 1995 & FAD & $\begin{array}{l}\text { Improve the system of } \\
\text { budgeting and public } \\
\text { expenditure control. }\end{array}$ & Initial steps taken. \\
\hline Spring 1995 & STA & $\begin{array}{l}\text { Harmonize the reporting } \\
\text { system for monetary } \\
\text { statistics. }\end{array}$ & $\begin{array}{l}\text { Harmonization } \\
\text { completed. }\end{array}$ \\
\hline Winter 1995 & STA & $\begin{array}{l}\text { Provide training in balance of } \\
\text { payments methodology. }\end{array}$ & Seminar provided. \\
\hline January 1996 & STA & $\begin{array}{l}\text { Improve foreign } \\
\text { trade statistics. }\end{array}$ & $\begin{array}{l}\text { Advice being } \\
\text { implemented. }\end{array}$ \\
\hline August 1996 & MFD (long term) & $\begin{array}{l}\text { Strengthen banking } \\
\text { supervision. }\end{array}$ & $\begin{array}{l}\text { Some of the advice } \\
\text { being implemented. }\end{array}$ \\
\hline October 1996 & STA & Improve national accounts. & $\begin{array}{l}\text { Some of the advice } \\
\text { being implemented. }\end{array}$ \\
\hline $\begin{array}{l}\text { January } 1996, \\
\text { November } 1996\end{array}$ & MFD & $\begin{array}{l}\text { Improve monetary and } \\
\text { foreign exchange operations. }\end{array}$ & $\begin{array}{l}\text { Some of the advice } \\
\text { being implemented. }\end{array}$ \\
\hline November 1997 & MFD & $\begin{array}{l}\text { Improve monetary } \\
\text { operations. }\end{array}$ & $\begin{array}{l}\text { Some of the advice } \\
\text { being implemented. }\end{array}$ \\
\hline May 1999 & MFD & $\begin{array}{l}\text { Review and advise on } \\
\text { monetary operations, the } \\
\text { payments system, and } \\
\text { supervision; assess } \\
\text { vulnerability of the financial } \\
\text { sector. }\end{array}$ & $\begin{array}{l}\text { Report } \\
\text { recommendations } \\
\text { being reviewed. }\end{array}$ \\
\hline July 2001 & MFD & Deposit insurance scheme. & $\begin{array}{l}\text { Report } \\
\text { recommendations } \\
\text { being reviewed. }\end{array}$ \\
\hline
\end{tabular}




\section{Zimbabwe: Relations with the World Bank Group ${ }^{14}$}

Zimbabwe went on nonaccrual (i.e. disbursements are suspended) status in October 2000. Arrears to the Bank as of April 27, 2004 amounted to US\$275.6 million. A resumption of lending would be contingent upon clearance of arrears. The scale of the Bank's subsequent reengagement will depend on progress on governance and macroeconomic stability. Currently, the Bank engagement in

Zimbabwe is limited to technical assistance and analytical work, primarily on macroeconomic policy, agriculture policy, social sector expenditure and social service delivery mechanisms, and HIV/AIDS. At the present time, the Bank is preparing an Interim Strategy Note to outline the Bank's role in Zimbabwe over the next 12-month period. The Strategy will focus on knowledge building, enhancing partnerships with in-country stakeholders including responsive parts of government, civil society and donor community, and facilitation of in-country dialogue on priority policy issues all in preparation for "re-engagement". Zimbabwe will have access to grant funds through a Trust Fund designated for countries in nonaccrual to support activities discussed in the Interim Strategy Note expected to be presented to the Bank Board of Executive Directors in September 2004.

The Bank continues to be active in maintaining a dialogue with donors, including (i) co-chairing quarterly donor coordinating meetings in Harare; (ii) contributing to UN thematic teams (chairing the Economic and Poverty Reduction Thematic Group); and (iii) providing technical advice to various UN initiatives, such as agriculture sector development, food security, and others.

Currently, the Bank does not have any active projects in Zimbabwe.

Zimbabwe had historically been one of the IFC's largest portfolios in Africa and hosted a strong private sector, with promising indigenous entrepreneurs complementing an established business community. The IFC's portfolio totals US\$24.9 million disbursed as of October 2003, with a concentration in the financial sector. IFC's current priorities are closely monitoring the existing portfolio and assisting companies with IFC investment in managing the current economic crisis. The IFC has provisioned investments substantially in Zimbabwe, in anticipation of losses.

World Bank Loan/Credit Summary for Zimbabwe (in millions of U.S. dollars; as of January 31, 2004)

\begin{tabular}{lrrr}
\hline & IBRD & \multicolumn{1}{l}{ IDA } & \multicolumn{1}{c}{ TOTAL } \\
\hline Original principal & & & \\
& 896.20 & 661.95 & $1,558.15$ \\
Cancellations & 53.21 & 194.82 & 248.04 \\
Disbursed & 842.91 & 459.08 & $1,301.99$ \\
Undisbursed & 0.08 & 8.69 & 8.77 \\
Repaid & 412.81 & 5.31 & 418.12 \\
Due & 430.10 & 489.88 & 919.98 \\
Exchange adjustment $^{15}$ & 20.99 & 0.00 & 20.99 \\
Borrower's obligation $^{15}$ & 451.09 & 489.88 & 940.97 \\
\hline
\end{tabular}

\footnotetext{
${ }^{14}$ For further information, please contact Ms. Ovadiya at (202)-473-2960.

${ }^{15}$ Does not include interest arrears.
} 


\section{Zimbabwe: Statistical Issues}

The economic and financial statistics database in Zimbabwe is inadequate, its quality is deteriorating, and data provision to the Fund is not timely. While some monetary data are of adequate quality, foreign reserves are not reported in a meaningful fashion by the Reserve Bank of Zimbabwe (RBZ), data on external arrears are not reported systematically, and budgetary and monetary data are reported to the staff with a substantial lag. The Central Statistical Office (CSO) conducts several sectoral surveys, but GDP data are reported with a substantial lag and harbor major inconsistencies. There are also shortcomings in external trade and finance data, and no information is available about unemployment and wages.

Zimbabwe participates in the General Data Dissemination System (GDDS) project for Anglophone African countries. Metadata for Zimbabwe (posted on the Fund's Dissemination Standards Bulletin Board in November 2002) indicate the country's plans for improvements in macroeconomic, financial, and sociodemographic statistics. However, in the absence of technical assistance, and funding, progress in improving the quality, coverage, and timeliness of Zimbabwe's statistical base is likely to be slow.

\section{Real sector}

National accounts. The CSO benefited from substantial technical assistance from the Fund, the World Bank, and the United Kingdom in 1996-97. This allowed the CSO to publish revised national accounts in late 1997, covering the period 1985-96, with 1990 as the base year for constant price estimates. STA provided a peripatetic advisor to assist with the improvement of real sector statistics in 2001, but these efforts were discontinued because of the deteriorating security situation. While the revised national accounts are a significant improvement over the previous estimates, the coverage of economic activity in the informal sector remains poor. National accounts data for 2001 were not published until March 2004, and had inconsistencies between sectoral developments and other activity indicators, which are currently being considered.

Prices, production, labor. The CSO produces a monthly consumer price index. In 2001, the base year was changed from 1990 to 1995, using new weights based on a 1995-96 household survey. A manufacturing index is reported with a 1990 base, but with a significant lag. Data on employment and wages, which had very limited coverage, are no longer published. A comprehensive labor market survey is long overdue. No information is available on unemployment.

\section{Fiscal sector}

Key weaknesses continue to impair the analysis of fiscal developments and the formulation of appropriate adjustment policies. Monthly revenue and expenditure data for the central government are available with a lag of 6 to 8 weeks. There are discrepancies between the budget financing need (computed from the income/expenditure side) and financing data from 
banking and other sources. In addition, a significant part of donor-financed development expenditure is off budget, the economic classification of expenditure is insufficiently disaggregated, and a functional classification of expenditure is not available. Large quasifiscal operations by the RBZ and significant contingent liabilities, including in the form of loan guarantees, are not systematically reported.

The authorities do not provide Fund staff with budget data according to organizational classification on a regular basis. They also provide limited access to source data, so staff has to rely on aggregated data of unverifiable quality. Also, the operations of the social security fund and several self-financing funds under the purview of the central government are not included in reported data. Furthermore, although operating targets for public enterprises are provided occasionally, it is still not possible to compile reliable consolidated accounts for the nonfinancial public sector, since financial operations of public enterprises are neither reported nor audited regularly, the accounts of local governments become available only with a lag of several years, and consolidated general government accounts are not compiled.

The latest published data in the Government Finance Statistics (GFS) Yearbook are for 1997. No more recent fiscal data have been provided for publication in International Financial Statistics (IFS).

\section{Financial sector}

Significant progress has been made in developing a unified system for reporting monetary statistics to the Fund based on international standards of data classification, and in improving the collection and reporting of financial data. However, there continues to be some difficulty in reconciling the balance sheet of the RBZ provided in the monetary control program with the monetary survey. More recently, an issue has emerged with respect to the accounting for financial bills issued by the RBZ in the monetary data. The monetary control program used to be available within two weeks of the end of each month, and the monetary survey was produced within six-eight weeks of the end of each month; recently, delays in submitting these data have increased to 2-3 months. In addition, serious deficiencies were found in the data reported to STA. Specifically, in the central bank accounts, negative figures are recorded for gold (May 2003) and SDR holdings (May, June, and September 2003). In the commercial banks accounts, negative figures are recorded for commercial bank bills payable (OctoberDecember 2003).

\section{External sector}

There is a pressing need for the authorities to compile and provide comprehensive external sector data on a more timely basis.

The trade balance in goods is still being reported with lags of more than four-five months, even though, following the installation of the new Automated System for Customs Data (ASYCUDA) at the customs department, data are being provided by customs to the CSO within seven days of the end of each month. Private remittance inflows have become 
significant in recent years, but the authorities report only the remittances received through official channels, which are miniscule.

Compilation of capital and financial account transactions suffers from considerable delays, and there is a significant lag in reporting balance of payments data to the Fund. The RBZ provides estimates of the balance of payments for surveillance purposes, but these require substantial adjustments. Measures are also needed to improve the estimates and shorten the lag in the compilation and reporting of such data. Balance of payments data published in the IFS and Balance of Payments Yearbook are even less timely - the latest data are for 1994, as annual data through 2001 provided for publication are of questionable quality. Data on shortterm external debt are reported to the Fund by the RBZ with a one- to two-month lag. External debt data (by debtor/creditor) are forthcoming only with a considerable lag and information on the terms and maturity profile of the external debt is not systematically available from the authorities. The authorities have provided staff only with partial information on the extent of their collateralized external borrowing.

There are no data available on Zimbabwe's international investment position.

Because of encumbrances on reserves, official reserve data are not reported to the Fund in a meaningful manner. From time to time, the RBZ provides data on "usable reserves."

\section{Sociodemographic data}

The CSO produces various sociodemographic statistics, offering information on population, the provision of health and education services, and indicators of poverty. However, since the data are usually collected through infrequent surveys and population censuses, the information provided in these statistics is often outdated. 


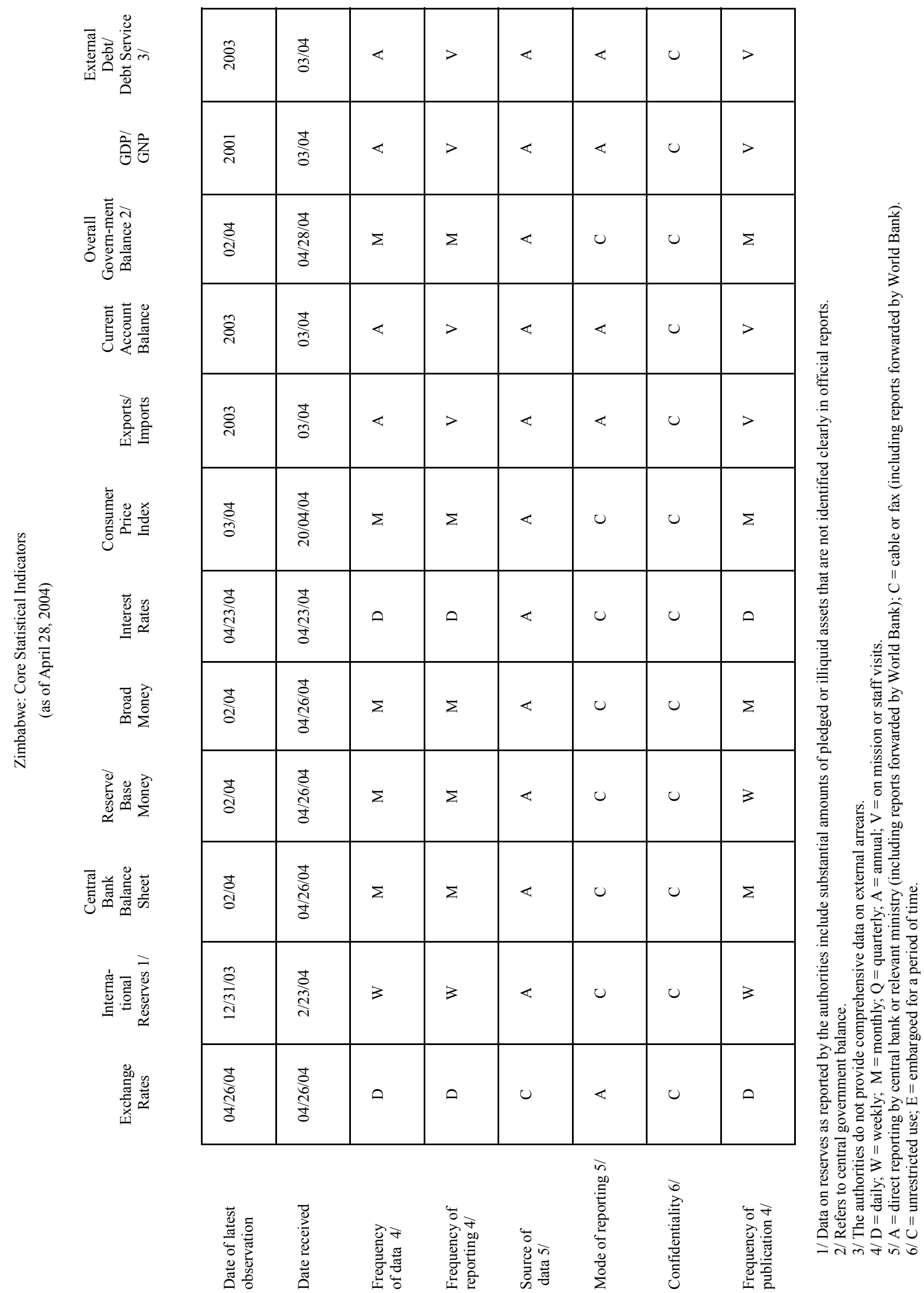




\section{Illustration of Zimbabwe's External Debt Situation}

With Zimbabwe's economic collapse, the debt situation has worsened. Foreign exchange shortages have led to a cessation of external debt repayments beginning in 2000. External arrears are estimated to amount to US $\$ 1.8$ billion, or 44 percent of the total debt by end2003. Exports have fallen by a cumulative 45 percent since their 2000 peak. The outlook is expected to worsen in 2004, and any subsequent recovery in exports will likely be gradual.

The bleak debt outlook indicates a need for future debt relief. For illustrative purposes, staff estimated the potential effect of full use of traditional debt relief mechanisms on Zimbabwe's debt, simulating a hypothetical stock treatment on Naples terms by bilateral and commercial creditors at end-2005 (a rescheduling of all ODA debt and a two-thirds reduction in the stock of non-ODA debt). The simulation assumed policy adjustments in 2005 and a recovery in exports. The NPV-to-exports ratio would be reduced from a projected 322 percent of exports before debt relief at end-2005 to 215 percent after the simulated relief.

Zimbabwe, Public and Publicly-Guaranteed External Debt Simulation

\begin{tabular}{|c|c|c|c|c|c|}
\hline & 2001 & 2002 & 2003 & $\begin{array}{l}2004 \\
\text { Proj. }\end{array}$ & $\begin{array}{l}2005 \\
\text { Proj. }\end{array}$ \\
\hline Nominal Stock (US\$ million) ${ }^{1}$ & 3,762 & 3,922 & 4,067 & 4,235 & 4,356 \\
\hline (In percent of GDP) & 44 & 51 & 57 & 62 & 62 \\
\hline (In percent of exports of goods and services) & 207 & 244 & 289 & 326 & 320 \\
\hline Of which: arrears (US\$ million) & 797 & 1,253 & 1,754 & $\ldots$ & $\ldots$ \\
\hline (In percent of GDP) & 9 & 16 & 25 & $\ldots$ & $\ldots$ \\
\hline \multicolumn{6}{|c|}{ NPV of Debt (in percent of exports of goods and services) } \\
\hline Before Naples Simulation & ... & $\ldots$ & 296 & 330 & 322 \\
\hline After Naples Simulation & $\ldots$ & $\ldots$ & $\ldots$ & $\ldots$ & 215 \\
\hline \multicolumn{6}{|l|}{ Memorandum item: } \\
\hline Exports of Goods and Services (US\$ million) & 1,818 & 1,607 & 1,409 & 1,298 & 1,363 \\
\hline
\end{tabular}

\footnotetext{
${ }^{1}$ Medium- and long-term debt only. Total debt figures in the BOP are higher as they also include shortterm public and publicly-guaranteed debt, and private external debt.
} 


\section{Statement by the IMF Staff Representative July 7, 2004}

1. This statement reports on information that has become available since the staff report was issued. It does not change the thrust of the staff appraisal.

2. In a continuation of developments since early 2004, monthly inflation remained at 6 percent in May 2004. The year-on-year rate fell to 449 percent, from 505 percent in April (Figures 1 and 2).

Figure 1. Monthly inflation (percent change)

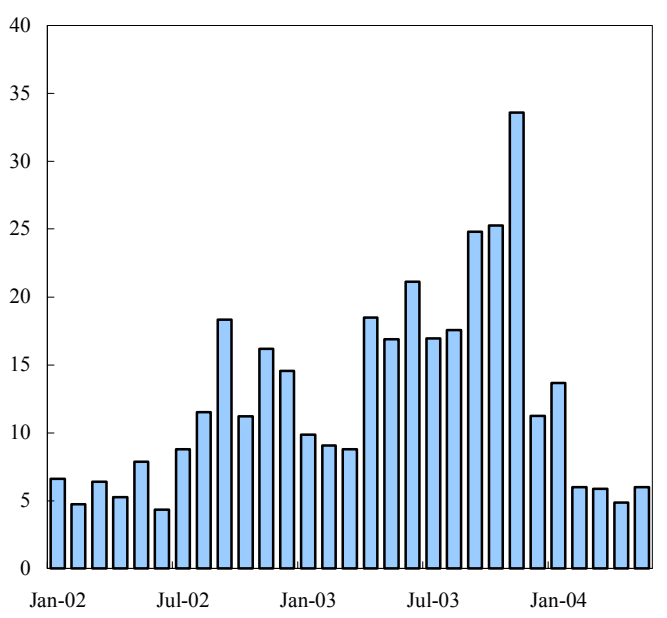

Figure 2. Money growth, inflation and parallel exchange rate

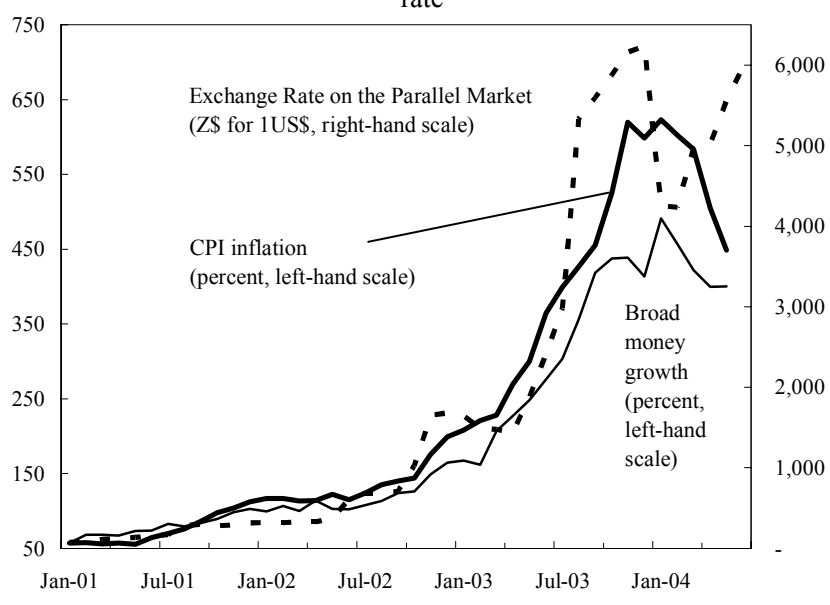

3. Broad money grew by 400 percent in the year to May 2004, largely driven by credit to the private sector (Figure 2). Credit was boosted by very large increases in credit from the Reserve Bank of Zimbabwe (RBZ) to domestic money banks under the highly concessional productive sector finance facility. Regarding liquidity management, at end-March 2003 the RBZ stopped issuing the 900-percent effective interest rate paper that it had used to mop up liquidity. When large amounts of the RBZ paper started falling due in mid-June 2003, the RBZ introduced a new liquidity management policy. Contrary to the staff's advice to move to market-based policies, the RBZ now compulsorily converts any surplus in the money market at the close of each day into new "open market" treasury bills with much longer maturities (up to 2 years) than that of the bulk of outstanding treasury bill (90 days) and at negative real interest rates (nominal effective rates of 70-100 percent).

4. Usable gross official reserves increased from US\$18 million at end-2003 to US\$76 million at end-May 2004, in response to the clampdown on the parallel market, which brought back foreign transactions into official channels, and with the beginning of the tobacco season in April. Reflecting the heavy management of the tender system, the tender rate, which had depreciated somewhat in March and April 2004, has remained largely unchanged since then at around Z\$5,350/US\$, even though demand has increased (Figure 3). 
The exchange rate in the parallel market reportedly depreciated to over $Z \$ 6,000$ in mid-June 2004, probably as a response to the widening gap between supply and demand of foreign exchange at the tender (Figures 2 and 3 ).

Figure 3. Zimbabwe: Foreign Exchange Tender
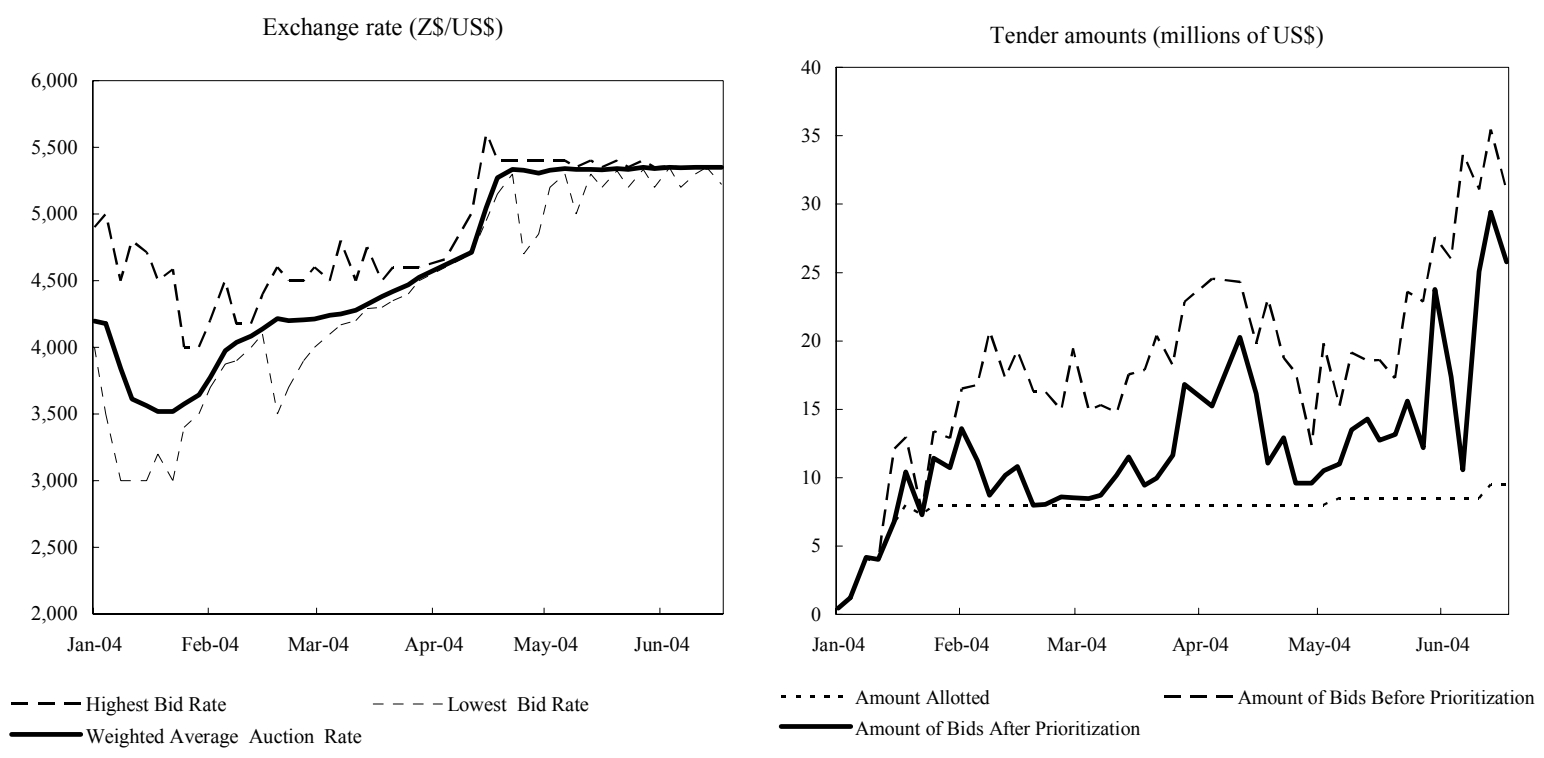

5. The fiscal deficit widened through April 2004, as an increase in revenue collection was more than offset by higher expenditure. This resulted in a cumulative deficit over the first four months of the year of 18 percent of GDP, up from a revised deficit of 17 percent of GDP in the first quarter. Little additional detail is available.

6. In early June 2004, Zimbabwe made payments of US\$1.5 million to the World Bank and US\$1.2 million to the African Development Bank, in line with the RBZ's recent policy to begin making some payments on arrears to multilateral creditors other than the IMF.

7. In other developments, on June 10, 2004, the government closed down an independent weekly newspaper. Ahead of the general elections in March 2005, the government has reportedly accepted the election guidelines drawn up by the South African Development Community (SADC) which recommend that voting take place in a single day, under the supervision of a new electoral commission. 


\section{INTERNATIONAL MONETARY FUND}

EXTERNAL

Public Information Notice PIN No. 04/104

FOR IMMEDIATE RELEASE

September 17, 2004
International Monetary Fund

$70019^{\text {th }}$ Street, NW

Washington, D. C. 20431 USA

\section{IMF Concludes 2004 Article IV Consultation with Zimbabwe}

On July 7, 2004, the Executive Board of the International Monetary Fund (IMF) concluded the Article IV consultation with Zimbabwe. ${ }^{1}$

\section{Background}

Zimbabwe's social and economic conditions have continued to deteriorate, mainly reflecting inadequate economic policies and structural changes that weakened the economic base.

In particular, the disorderly implementation of the land reform program has contributed to a sharp reduction in agricultural production. Concerns about governance, the rule of law and human rights, and the continued lack of clarity about property rights have severely damaged confidence, discouraged investment, and promoted capital flight and emigration, thus contributing to the economic decline. Unemployment is very high and increasing, social indicators have worsened, and the widespread HIVIAIDS pandemic remains largely unchecked. Severe food shortages have necessitated massive food imports and donor assistance.

Real GDP declined by 9.3 percent in 2003 and another broad-based decline is projected this year. Year-on-year inflation reached 600 percent during November 2003-February 2004. However, monthly inflation, which had reached 34 percent in November 2003, fell to 5 percent in April 2004 following a tightening of monetary policy and an appreciation of the exchange rate.

\footnotetext{
${ }^{1}$ Under Article IV of the IMF's Articles of Agreement, the IMF holds bilateral discussions with members, usually every year. A staff team visits the country, collects economic and financial information, and discusses with officials the country's economic developments and policies. On return to headquarters, the staff prepares a report, which forms the basis for discussion by the Executive Board. At the conclusion of the discussion, the Managing Director, as Chairman of the Board, summarizes the views of Executive Directors, and this summary is transmitted to the country's authorities. This PIN summarizes the views of the Executive Board as expressed during the July 7, 2004 Executive Board discussion based on the staff report.
} 
Monetary policy was loose and fueled high inflation in 2003 , but it has been tightened in recent months, albeit not consistently. Broad money growth increased to 400 percent in December 2003, spearheaded by an expansion in private sector credit of above 520 percent. During the first two months of 2004, the Reserve Bank injected the equivalent of two-and-a-half times the money stock at end-2003 through liquidity support to some banks and a concessional facility at a highly negative interest rate aiming to support "productive" sectors. Soon after, however, it began to mop up at high interest rates the excess liquidity that was created that way.

Fiscal operations were almost balanced in 2003, but the 2004 budget is expansionary, with a deficit target of 7.3 percent of GDP. Expenditure fell sharply in real terms in 2003 as wages were eroded by inflation, the domestic interest bill declined owing to negative real interest rates, and other government spending was constrained by shortages of foreign exchange and the weakening administrative capacity. The budget deficit rose to 13.4 percent of quarterly GDP in the first quarter of 2004, following a 220 percent wage increase in January and a catch up in current and capital spending.

The external current account deficit narrowed to 6.0 percent in 2003, from 7.3 percent in 2002. In the absence of foreign financing, arrears continued to accumulate to reach US\$2.1 billion, or 44 percent of external debt. The average exchange rate in the economy strongly appreciated in early 2004 . This resulted from the introduction of a heavily managed foreign exchange tender system in January and the clamping down on the parallel market, where the bulk of foreign exchange transactions took place in 2003. In April 2004, the average exchange rate was some 40 percent appreciated relative to the parallel exchange rate at end-2003. The tender rate depreciated somewhat in early May.

Progress has been limited on structural reforms. Most price controls were removed after May 2003 and the fuel market was partially liberalized. However, other reforms, including civil service reform and privatization, have stalled, and problems relating to the land reform program and property rights continued to affect adversely economic activity.

Zimbabwe has incurred overdue financial obligations to the Fund since February 2001. Arrears to the Fund totaled SDR 197 million as of end-April 2004.

\section{Executive Board Assessment}

They expressed grave concern over the continued sharp economic decline and high inflation in Zimbabwe, which are having dire consequences for the country's population-notably rising unemployment and the rapid deterioration of social indicators-that in the past were among the best in Africa. They regretted that a cycle of malnourishment and disease has developed, and that the sharp fall in agricultural production has led to continued food insecurity, while one in four adults is HIV-positive.

Directors saw the crisis as resulting mainly from inappropriate macroeconomic and structural policies, including weak financial management, distortionary controls and regulations, and the disorderly implementation of the fast-track land reform. External factors have compounded the 
effects of these policies. More broadly, Directors regretted that weak governance, corruption and the lack of respect for the rule of law have undermined confidence and led to capital flight and emigration, with negative spillover effects on neighboring countries.

Directors noted the government's efforts in 2003 to tighten the monetary stance. However, most Directors considered that the policies implemented to tackle the crisis have been inadequate and unsustainable. They strongly urged the authorities to adopt a comprehensive policy package aimed at halting the deterioration of the socio-economic situation, restoring confidence and donor support, and restarting growth on a sustainable basis.

Directors expressed concern about the expansionary budget for 2004 as well as the recent deterioration of the fiscal situation, and stressed that a decisive fiscal effort is needed urgently to help ease inflationary pressures. They advised the government to exercise strict control over the wage bill and non-essential spending and, at the same time, to do their utmost to protect social and infrastructure outlays and food imports if necessary. It will also be important to reduce quasi-fiscal activities, better target subsidies, and eliminate ad hoc tax exemptions in order to strengthen revenues.

Directors considered that reducing inflation should be the authorities' main priority and called for a sustained tightening of monetary policy. In this context, they stressed the urgent need to contain the growth of credit-in particular, credit at preferential, non-market interest rates-and to improve short-term liquidity management. Directors emphasized the importance of eliminating the current system of dual interest rates, which has led to serious distortions in the financial system, including disincentives to savings. They urged that market forces be permitted to determine interest rates and that concessional lending to selected borrowers be phased out.

Directors encouraged the authorities to step up their efforts to strengthen financial sector supervision, particularly with regard to provisioning and capital adequacy. They advised the Reserve Bank of Zimbabwe to prepare for the restructuring of weak and unsound banks, and to reduce systemic risks, including those associated with the concentration of lending among few firms. Directors considered that stronger supervision will be essential to help contain the effects of tighter financial policies and instill confidence in the domestic banking system.

Directors observed that the foreign exchange system continues to be affected by distortions caused by government intervention and burdensome surrender requirements. They called for a unification of the exchange rate to fully reflect market factors and improve external competitiveness, as well as for the removal of surrender requirements.

Directors encouraged the authorities to further liberalize the trade regime. They regretted that Zimbabwe maintains exchange restrictions on payments and transfers for current international transactions as well as multiple currency practices. They urged the authorities to establish a timetable for the removal of the restrictions and the elimination of the multiple currency practices. 
Directors strongly recommended that the authorities address the impediments to improving food security, including by replacing the monopoly of the Grain Marketing Board with well-targeted basic food subsidies. They expressed concern over the food security outlook for the coming year and noted the government's decision in early May to abort the crop assessment prepared together with the World Food Program. They regretted that this decision leaves Zimbabwe without a basis for a timely appeal for food aid, with serious humanitarian consequences should the crop fall short of the government's ambitious estimates.

Directors regretted that there has been little progress in the area of structural reform.

They emphasized that reforms focusing on increasing production and raising productivity and restoring respect for the rule of law remain critical for helping instill confidence and restarting economic growth. Directors recommended the removal of restrictive regulations to bring more activities into the formal economy, and the eventual privatization of public enterprises to reduce the fiscal burden and improve service delivery. They also advised the authorities to pursue anticorruption efforts more vigorously by focusing closely on the roots of corruption, namely the numerous economic distortions that provided rent-seeking opportunities, rather than on its symptoms.

Directors urged the authorities to address in a transparent and orderly manner problems relating to land reform. They stressed that the clarification of tenure rights will be crucial for raising agricultural production and facilitating access to credit for farmers.

Directors took note of the authorities' request for resumption of technical assistance, which was suspended by the Executive Board in 2002. Staff will continue to provide policy advice to help the authorities formulate and implement a comprehensive and consistent package of measures in the context of the Article IV consultation discussions.

Directors stressed the need to address growing deficiencies in the statistical system that hampered the analysis of economic developments, policy formulation and implementation.

Directors also reviewed Zimbabwe's overdue obligations to the Fund. They considered the resumption of partial payments by Zimbabwe to the Fund in 2004 as a positive step, but regretted that this will be insufficient to stabilize arrears. They called on the authorities to take more decisive actions to improve cooperation with the Fund by adopting economic policies to address Zimbabwe's serious economic problems, and by significantly increasing payments to the Fund. They agreed to consider again the Managing Director's complaint regarding Zimbabwe's compulsory withdrawal from the Fund within six months.

Public Information Notices (PINs) form part of the IMF's efforts to promote transparency of the IMF's views and analysis of economic developments and policies. With the consent of the country (or countries) concerned, PINs are issued after Executive Board discussions of Article IV consultations with member countries, of its surveillance of developments at the regional level, of post-program monitoring, and of ex post assessments of member countries with longer-term program engagements. PINs are also issued after Executive Board discussions of general policy matters, unless otherwise decided by the Executive Board in a particular case. The Staff Report for the 2004 Article IV Consultation with the Zimbabwe is also available. 
Zimbabwe: Selected Economic Indicators, 2000-03

2000

2001

2002

2003

Est.

Real economy (percentage change)

Real GDP (market prices)

$-7.9$

55.2

$-2.8 \quad-11.1$

$-9.3$

Consumer prices (end of period)

112

$198.9 \quad 598.7$

Government finances (percent of GDP)

Revenue, excluding grants

26.7

$24.1 \quad 25.2$

23.7

Expenditure and net lending

Overall balance, excluding grants and arrears

Primary balance, excluding grants

48.3

$33.5 \quad 29.2 \quad 24.0$

$\begin{array}{llll}-21.6 & -9.4 & -3.9 & -0.3\end{array}$

$\begin{array}{llll}-5.4 & 0.0 & 0.2 & 0.8\end{array}$

Money and interest rates

Broad money (M3, end of period; percentage change)

91-day treasury bills (annualized yield)

$\begin{array}{lrrr}59.9 & 102.7 & 164.8 & 413.5\end{array}$

$\begin{array}{llll}57.8 & 25.9 & 26.6 & 60.7\end{array}$

Balance of payments (billions of U.S. dollars; unless otherwise indicated)

Exports

Current account balance (excluding official transfers)

(In percent of GDP at the official exchange rate) ${ }^{1 /}$

(In percent of GDP at world prices) ${ }^{2 /}$

Overall balance

Usable reserves (millions of U.S. dollars; end of period) (months of imports of goods and services)

Total external debt (percent of GDP at official exchange rate; end of period) $1 /$

Total external debt (percent of GDP at world prices; end of period) $)^{2 /}$

Debt service (percent of exports of goods and services)

$\begin{array}{rrrr}2.20 & 1.58 & 1.40 & 1.23 \\ -1.91 & -1.79 & -1.92 & -1.63 \\ -0.04 & -0.50 & -0.60 & -0.42 \\ -0.5 & -4.8 & -2.8 & -4.8 \\ -0.4 & -5.9 & -7.9 & -6.0 \\ -0.14 & -0.27 & -0.64 & -0.57\end{array}$

$\begin{array}{llll}22.1 & 20.0 & 15.1 & 18.3\end{array}$

$\begin{array}{llll}0.1 & 0.1 & 0.1 & 0.1\end{array}$

$\begin{array}{llll}54.3 & 37.5 & 20.0 & 55.3\end{array}$

$\begin{array}{lll}31.4 & 57.0 \quad 68.4\end{array}$

$31.4 \quad 35.1 \quad 35.4$

Sources: Zimbabwean authorities; and IMF staff estimates and projections.

${ }^{1 /}$ Foreign currency units are converted into Zimbabwe dollars at the official exchange rate.

${ }^{2 /}$ GDP at world prices using real GDP growth and trading partner countries' inflation (base year is 1996). 